\title{
Wnt $/ \beta$-Catenin Signaling Is an Essential and Direct Driver of Myelin Gene Expression and Myelinogenesis
}

\author{
Marcel Tawk, ${ }^{1 *}$ Joelle Makoukji, ${ }^{2 \star}$ Martin Belle, ${ }^{2}$ Cosima Fonte, ${ }^{1}$ Amalia Trousson, ${ }^{2}$ Thomas Hawkins, ${ }^{3}$ Huiliang Li, ${ }^{4}$ \\ Said Ghandour, ${ }^{5}$ Michael Schumacher, ${ }^{1}$ and Charbel Massaad ${ }^{1,2}$ \\ ${ }^{1}$ Unité Mixte de Recherche (UMR) 788, Inserm and University Paris-Sud 11, Biomedical Institute of Bicêtre, 94276 Kremlin-Bicêtre, France, ${ }^{2}$ University \\ Paris Descartes, UMR8194 Centre National de la Recherche Scientifique (CNRS), 75270 Paris, France, ${ }^{3}$ Department of Cell and Developmental Biology, and \\ ${ }^{4}$ Wolfson Institute for Biomedical Research, Department of Cell and Developmental Biology, University College London, London WC1E 6BT, United \\ Kingdom, and ${ }^{5}$ CNRS FRE3289 and University of Strasbourg, 67085 Strasbourg, France
}

$\mathrm{Wnt} / \beta$-catenin signaling plays a major role in the development of the nervous system and contributes to neuronal plasticity. However, its role in myelination remains unclear. Here, we identify the Wnt/ $\beta$-catenin pathway as an essential driver of myelin gene expression. The selective inhibition of Wnt components by small interfering RNA or dominant-negative forms blocks the expression of myelin protein zero (MPZ) and peripheral myelin protein 22 (PMP22) in mouse Schwann cells and proteolipid protein in mouse oligodendrocytes. Moreover, the activation of Wnt signaling by recombinant Wntl ligand increases by threefold the transcription of myelin genes and enhances the binding of $\beta$-catenin to T-cell factor/lymphoid-enhancer factor transcription factors present in the vicinity of the MPZ and PMP22 promoters. Most important, loss-of-function analyses in zebrafish embryos show, in vivo, a key role for Wnt/ $\beta$-catenin signaling in the expression of myelin genes and in myelin sheath compaction, both in the peripheral and central nervous systems. Inhibition of Wnt/ $\beta$-catenin signaling resulted in hypomyelination, without affecting Schwann cell and oligodendrocyte generation or axonal integrity. The present findings attribute to $\mathrm{Wnt} / \beta$-catenin pathway components an essential role in myelin gene expression and myelinogenesis.

\section{Introduction}

Myelin sheaths are essential for the efficient conduction of action potentials and support the integrity of axons in the vertebrate nervous system. The myelination of axons is performed during development by Schwann cells in the peripheral nervous system (PNS) and by oligodendrocytes in the CNS. Myelination involves the extension of large sheaths of membranes and their wrapping around axons, accompanied by the coordinated synthesis of a variety of myelin components, including myelin-specific proteins (ffrench-Constant et al., 2004; Jessen and Mirsky, 2005). Although the morphology of myelin and its molecular constitution are well described, the signaling mechanisms involved in myelination and in the transcriptional control of myelin genes remain poorly understood.

Wnt ligands bind to the frizzled membrane receptors (FZD), which interact with coreceptors named the arrow/low-density lipoprotein receptor-related proteins (LRPs) (Lai et al., 2009). Wnt

Received Aug. 16, 2010; revised Dec. 14, 2010; accepted Dec. 30, 2010.

This work was supported by Inserm, Centre National de la Recherche Scientifique, University Paris Descartes, University Paris-Sud 11, and the Association Française contre les Myopathies. J.M., A.T., and M.B. received PhD fellowships from the French Ministry of Research. M.T. received a postdoctoral fellowship from Inserm (Poste Junior). T.H. was supported by the European Union (EU) FP6 project ZF-MODELS and latterly by the EU FP7 project NEUROXSYS. His work was undertaken in the laboratory of Stephen W. Wilson (University College London, London, UK), which also received support from the Wellcome Trust and the Biotechnology and Biological Sciences Research Council. We are grateful for Dr. P. P. Vidal and Prof. F. Charbonnier for the critical reading of this manuscript.

${ }^{*}$ M.T. and J.M. contributed equally to this work.

Correspondence should be addressed to Prof. Charbel Massaad, UMR 8194 CNRS, University Paris Descartes, 45 rue des Saints-Pères, 75270 Paris Cedex 6, France. E-mail: charbel.massaad@parisdescartes.fr.

DOI:10.1523/JNEUROSCI.4270-10.2011

Copyright $\odot 2011$ the authors $\quad 0270-6474 / 11 / 313729-14 \$ 15.00 / 0$ binding to FZD activates different intracellular signaling pathways, including an evolutionarily conserved branch, the so-called canonical Wnt signaling pathway or $\mathrm{Wnt} / \beta$-catenin pathway. In the absence of Wnt signal, $\beta$-catenin is phosphorylated by glycogen synthase kinase $3 \beta$ (GSK3 $\beta$ ) and is then targeted for proteasomal degradation. Wnt signaling through FDZ and LRP activates the cytoplasmic phosphoprotein disheveled (DSH), which prevents $\beta$-catenin degradation. The stabilized $\beta$-catenin enters the nucleus, where it regulates gene transcription by interacting with transcription factors called the T-cell factor/lymphoid-enhancer factors (TCF/LEF or TCFs) that bind to a consensus TCF/LEF response element, $(\mathrm{A} / \mathrm{T})(\mathrm{A} / \mathrm{T}) \mathrm{CAA}(\mathrm{A} / \mathrm{T}) \mathrm{G}$, present in the cognate promoters (van Beest et al., 2000). Four different forms of TCFs are expressed in mouse tissues: TCF1, LEF1, TCF3, and TCF4. In the absence of nuclear $\beta$-catenin, the TCFs interact with transcriptional repressors and prevent Wnt target gene transcription (Bienz, 1998; Cavallo et al., 1998; Chen et al., 1999). However, when Wnt signaling is activated, the interaction with $\beta$-catenin converts the TCF into transcriptional activators (Nusse, 1999).

Wnt signaling is known to play a key role in neurogenesis and the fate of neural progenitors (Lee et al., 2004; Gao et al., 2007). Moreover, it has been identified as a major regulator of neuronal circuit formation during development, involved in neuron positioning, polarization, axon and dendrite development, and synaptogenesis (Salinas and Zou, 2008). In the adult brain, Wnt signaling continues supporting the proper functioning and viability of neurons (Toledo et al., 2008).

An involvement of $\beta$-catenin signaling in myelin formation has recently been described. The constitutive overexpression or 
activation of $\beta$-catenin, and the disruption or inhibition of TCF, were found to impair the development of oligodendrocytes (Fancy et al., 2009; Feigenson et al., 2009; Ye et al., 2009). However, the role of canonical Wnt signaling in the control of myelination and myelin gene expression in Schwann cells and oligodendrocytes remains undetermined. Here, we report that $\mathrm{Wnt} / \beta$-catenin signaling operates as a key driver of myelin gene expression and myelination. Our findings thus represent a major conceptual advance in the transcriptional control of myelin gene expression, and they cast a new insight on the role of Wnt signaling in developmental myelination.

\section{Materials and Methods}

Cell cultures. The mouse Schwann cell line MSC80 exhibits normal Schwann cell characteristics [S100, myelin protein zero (MPZ), peripheral myelin protein 22 (PMP22) expression] and has retained the capacity to myelinate axons (Boutry et al., 1992; Baron-Van Evercooren et al., 1993). The $158 \mathrm{~N}$ oligodendrocyte cell line originates from mature oligodendrocytes. It derives from normal oligodendrocytes in secondary cultures that were transfected with plasmids containing the SV40 T-antigen gene expressed under the control of the mouse metallothionein-I promoter. The immortalized stable cell line $(158 \mathrm{~N})$ expresses transcripts and proteins of oligodendrocyte markers, including proteolipid protein (PLP), myelin basic protein (MBP), and carbonic anhydrase II (CA II). Galactocerebroside and sulfatide are also detected with immunocytochemistry. In the $158 \mathrm{~N}$ cell line, the levels of oligodendrocyte markers (PLP, MBP, and CAII) are significantly increased by dibutyryl cAMP (dbcAMP) treatment. As the $158 \mathrm{~N}$ cell line continues to express properties of oligodendrocytes, it provides a powerful model to explore the function and regulation of myelin proteins (Feutz et al., 2001; Trousson et al., 2009). Both cell lines were maintained in DMEM supplemented with $10 \%$ or $5 \%$ decomplemented fetal calf serum (FCS), respectively (Hyclone-Perbio), $100 \mathrm{U} / \mathrm{ml}$ penicillin, and $100 \mu \mathrm{l} / \mathrm{ml}$ streptomycin (Invitrogen). All cultures were grown at $37^{\circ} \mathrm{C}$ in a humidified atmosphere of $5 \% \mathrm{CO}_{2}$.

Primary cell culture. Primary mouse Schwann cell cultures were obtained from postnatal day 0 ( $\mathrm{P} 0$ ) to $\mathrm{P} 2$ sciatic nerves. In brief, nerves were digested in enzyme buffer $(0.7 \mathrm{mg} / \mathrm{ml}$ collagenase type I and $0.25 \%$ trypsin in HBSS; Invitrogen). After trituration, cells were grown on poly-Dlysine/laminin-coated dishes in minimal medium plus 5\% FCS. Minimal medium is DMEM/F-12 (Invitrogen), containing $100 \mu \mathrm{g} / \mathrm{ml}$ human apo-transferrin, $60 \mathrm{ng} / \mathrm{ml}$ progesterone, $5 \mathrm{mg} / \mathrm{ml}$ insulin, $16 \mu \mathrm{g} / \mathrm{ml} \mathrm{pu}$ trescine, $400 \mathrm{ng} / \mathrm{ml}$ L-thyroxine, $160 \mathrm{ng} / \mathrm{ml}$ selenium, $10 \mathrm{ng} / \mathrm{ml}$ triiodothyronine, and $300 \mathrm{mg} / \mathrm{ml}$ bovine serum albumin (BSA; Fluka).

Primary glial cell cultures were prepared from newborn mouse brain hemispheres derived from PLP::GFP mice [a generous gift from Dr. W. Macklin (Cleveland Clinic Foundation, Cleveland, OH) (Mallon et al., 2002)] as described previously (Feutz et al., 2001). Briefly, meninges were removed, and cerebral hemispheres were mechanically dissociated in DMEM supplemented with $10 \%$ calf serum (Invitrogen), penicillin (50 $\mathrm{U} / \mathrm{ml})$, and streptomycin $(50 \mu \mathrm{g} / \mathrm{ml})$. The cell suspension was plated in a 60-mm-diameter Petri dish (one brain per two Petri dishes) coated with 20 $\mu \mathrm{g} / \mathrm{ml}$ poly-L-lysine (Sigma). Cultures were then incubated in $5 \% \mathrm{CO}_{2}$ and $95 \%$ air in a humidified atmosphere $(90 \%)$ at $37^{\circ} \mathrm{C}$. The cultures were kept for either $4 \mathrm{~d}$ [they contain $>70 \%$ of oligodendrocytes progenitor cells (OPCs)] or $12 \mathrm{~d}$ in vitro (they contain $>70 \%$ of mature oligodendrocytes).

Plasmids and chemicals. MPZ-luc was graciously provided by Dr. G. Lemke (Salk Institute, La Jolla, CA), PMP22-luc was provided by Dr. P. Patel (Baylor College of Medicine, Houston, TX; it contains the promoter 1 of PMP22, whose expression is confined to the PNS), PLP-luc was provided by Dr. W. Macklin, Dsh-dn plasmids were provided by Dr. M. Tada (University College London, London, UK), (Tada and Smith, 2000), and TOP-Flash-luc plasmid was provided by Dr. R. T. Moon (University of Washington School of Medicine, Seattle, WA). The nuclear-localized $\beta$-catenin expression vector (NL- $\beta$-catenin) was provided by Dr. M. A. Buendia (Pasteur Institute, Paris, France). PCS2+ vectors carrying a cDNA fragment encoding LRP6 $\Delta \mathrm{C}$ (Tamai et al., 2000) were used in this study. mRNA was synthesized using the SP6 mMessage mMachine System (Ambion), and we injected 250-300 pg of
LRP6 $\Delta$ C mRNA per embryo. The small interfering RNAs (siRNAs) directed against the four TCFs (TCF1, LEF1, TCF3, and TCF4) and nontargeting siRNA (NT) were purchased from Dharmacon. Each TCF was targeted with four different sequences of siRNA directed against four different regions of the cognate mRNA. The small interfering $\beta$-catenin vector was described by Fonte et al. (2005). Wntl was purchased from Biovision.

Transient transfections. MSC80 and $158 \mathrm{~N}$ cells were transiently transfected using Effecten reagent (Qiagen). One day before the transfection, cells $\left(1.5 \times 10^{5}\right.$ cells/well $)$ were grown into six-well plates and incubated in the DMEM culture medium containing $10 \%$ or $5 \%$ decomplemented FCS. The MPZ-luc or the PMP22-luc or PLP-luc plasmid $(0.3 \mu \mathrm{g})$, the pRSV- $\beta$-galactosidase expression vector $(0.1 \mu \mathrm{g})$, and the dominantnegative expression vectors, mock vectors, or siRNAs at the concentrations indicated in the figure legends were mixed with a solution containing Effecten reagents $(0.85 \mathrm{mg} / \mathrm{ml})$ in DMEM. The mixture was then added to cells and incubated overnight. Sixteen hours after transfection, the medium was replaced by DMEM. Luciferase activity was determined using the enzymatic method described by Massaad et al. (2000). The $\beta$-galactosidase activity was used to normalize the transfection efficiency.

Quantitative and semiquantitative real-time PCR experiments. Total RNA from cultured cells was obtained using RNA NOW (Ozyme). One microgram was reverse transcribed with random primers (Promega) and reverse transcriptase M-MLV-RT (Invitrogen). PCR experiments were performed using TaqDNA polymerase purchased from Promega and primers specific to each gene from Operon. PCR products were analyzed on an agarose gel $(2 \%)$ and visualized under UV.

Quantitative real-time PCR (qRT-PCR) was performed with standard protocols using SYBRGreen ROX Mix (ABgene) as a fluorescent detection dye in ABI PRISM 7000 in a final volume of $10 \mu$ l, which also contained 300 nM primers (Operon) and 20 ng of reverse-transcribed RNA in 384-well plates. To characterize the generated amplicons and to control for the contamination by unspecific byproducts, a melting curve analysis was applied. Each reaction was performed in triplicate, and the mean of at least three independent experiments was calculated. All results were normalized to the 26S mRNA level and calculated using the Delta Ct method. The primer sequences used in RT-PCR are listed as follows: MPZ forward (F) 5' GTCAAGTCCCCCAGTAGAA 3'; MPZ reverse (R) 5' AGGAGCAAGAGGAAAGCAC 3'; PMP22 F 5' AATGGACACACGACTGATC 3'; PMP22 R 5' CCTTTGGTGAGAGTGAAGAG 3'; PLP F 5' AGCAAAGTCAGCCGCAAAAC $3^{\prime}$; PLP R 5' CCAGGGAAGCAAAGGGGG 3'; Wnt1 F 5' ATGAACCTTCACAACAACGAG 3'; Wnt1 R 5' GGTTGCTGCCTCGGTTG 3'; Wnt3 F 5' CAAGCACAACAATGAAGCAGGC 3'; Wnt3 R $5^{\prime}$ TCGGGACTCACGGTGTTTCTC 3'; Wnt3a F 5' CACCACCGTCAGCAACAGCC 3'; Wnt3a R 5' AGGAGCGTGTCACTGCGAAAG 3'; Wnt7a F $5^{\prime}$ CGACTGTGGCTGCGACAAG 3'; Wnt7a R 5' CTTCATGTTCTCCTCCAGGATCTTC $3^{\prime}$; TCF1 F $5^{\prime}$ TCAAGAGGTGGGGGATTAGA $3^{\prime}$; TCF1 R 5' GCAGGAGAAGCATTTGTAGG 3'; LEF1 F 5' AAGCCTCAACACGAACACAG $3^{\prime}$; LEF1 R 5' TGCACTCAGCTACGACATTC $3^{\prime}$; TCF3 F 5' ACCCCTTCCTGATGATTCC 3'; TCF3 R 5' CGACCTTGTGTCCTTGACT 3'; TCF4 F 5' CACGACAGGAGGATTCAGA 3'; TCF4 R 5' GGGGCTTCTTCTTCTCTTC $3^{\prime}$; 26S F $5^{\prime}$ AGGAGAAACAACGGTCGTGCCAAAA 3'; 26S R 5' GCGCAAGCAGGTCTGAATCGTG 3'; 18S F 5' CTACCACATCCAAGGAAGGC $3^{\prime}$; 18 S R $5^{\prime}$ CTCGGGCCTGCTTTGAACAC $3^{\prime}$; MPZ (-8487/-8471) F 5' GGTCCTGAGTTCAAATCCC $3^{\prime}$; MPZ $(-8487 /-8471)$ R 5' GAACCTTCATCTGTTGTTGG 3'; MPZ (-5487/ -5461) F $5^{\prime}$ TCTCTGGACAGAAAATGGAC $3^{\prime}$; MPZ (-5487/-5461) R $5^{\prime}$ TTAACTCCTGGCAATCCTG $3^{\prime}$; PMP22 $(+107 /+124)$ F 5' GCTCCACCAGAGAACCTC 3'; PMP22 $(+107 /+124)$ R 5' TGCCAATCAAACTCACCAGAC 3'; EF $1 \alpha$ F 5' CTTCTCAGGCTGACTGTGC3'; EF $1 \alpha$ R 5' CCGCTAGCATTACCCTCC $3^{\prime}$; MBP F 5' TCCTCTCCTCGTCCTAAGTC 3'; MBP R 5' TCCATCTCAGTGTTTTCCTG 3'.

Antibodies. Primary antibodies against MPZ (rabbit polyclonal), PMP22 (rabbit polyclonal), Wnt1 (rabbit polyclonal), LRP6 (goat polyclonal), and $\beta$-actin (rabbit polyclonal) were purchased from Abcam; primary antibodies against $\beta$-catenin (mouse monoclonal) were purchased from BD Biosciences; and primary antibodies against DSH-2 (rabbit), GSK3 $\beta$ (rabbit), LEF1/TCF (mouse), and MBP (rabbit poly- 
clonal) were purchased from Millipore. Secondary antibodies used for Western blotting were HRP-conjugated goat anti-mouse IgG and HRPconjugated goat anti-rabbit IgG (Millipore). Secondary antibodies used for immunofluorescence studies were Alexa 488 goat anti-mouse and Alexa 555 donkey anti-rabbit purchased from Invitrogen.

For zebrafish, we used the following primary antibodies: antiacetylated tubulin (Sigma), anti-phosphohistone H3 (Millipore). Secondary antibodies used were Alexa 488 or Alexa 568 (Invitrogen).

Western blot. Protein content was determined using the "RC-DC" protein assay kit (Bio-Rad) with BSA as the standard. Aliquots of $20 \mu \mathrm{g}$ of total MSC80 extracts treated or not with Wnt $1(10 \mathrm{ng})$ were used for each sample. Homogenate proteins were separated on $15 \%$ SDS-polyacrylamide gels by electrophoresis and blotted onto polyvinylidene difluoride membranes. Nonspecific binding sites in the transblots were blocked at $4^{\circ} \mathrm{C}$ overnight with $2 \%$ ECL Advance blocking agent (GE Healthcare) and with $0.1 \%$ Tween 20 (Invitrogen) in PBS. Membranes were then incubated at room temperature for $2 \mathrm{~h}$ with the following primary antibodies diluted in a mixture of $2 \%$ ECL Advance blocking agent and PBS- $0.1 \%$ Tween: MPZ antibody (1:750), PMP22 antibody (1:750), $\beta$-catenin antibody $(1: 1000)$, and $\beta$-actin antibody $(1: 10,000)$. They were then incubated at room temperature for $1 \mathrm{~h}, 30 \mathrm{~min}$ with the appropriate secondary antibody diluted in $2 \%$ blocking buffer/PBS- $0.1 \%$ Tween (anti-mouse, 1:20,000; anti-rabbit, 1:20,000), followed by ECL Plus Western blotting detection (GE Healthcare) before exposure to radiographic film Hyperfilm ECL (GE Healthcare).

Immunocytochemistry. MSC80 Schwann cells were grown at the density of $0.4 \times 10^{5}$ cells in two-well glass slides (Lab-Tek; Nalge Nunc International). Cells were then fixed with paraformaldehyde (4\%) for 20 min. After three washes with PBS $(1 \times)$, cells were permeabilized with Triton X-100 (1\%) for $30 \mathrm{~min}$. Then, cells were incubated with primary antibodies against Wnt1 (dilution, 1:100), LRP6 (dilution, 1:100), DSH (dilution, 1:100), GSK3 $\beta$ (dilution, 1:100), $\beta$-catenin (dilution, 1:250), or TCF/LEF1 (dilution, 1:100) overnight at $4^{\circ} \mathrm{C}$ and labeled with conjugated antibodies (dilution, 1:500) for $1 \mathrm{~h}$ in the dark at room temperature. The slides were imaged using a confocal microscope (LSM510; Carl Zeiss) with a $40 \times$ [numerical aperture (NA) 1.2] lens, and sequential excitation was performed with laser lines $488 \mathrm{~nm}$ (Ar.ion laser) and $633 \mathrm{~nm}$ (HeNe laser). The DNA dye TO-PRO-3 (red) was used to identify the nuclei.

Immunohistochemistry. Sciatic nerves of mice aged 7 or $21 \mathrm{~d}$ were dissected and immediately fixed with 4\% paraformaldehyde for $24 \mathrm{~h}$. Nerve cross sections $(10 \mu \mathrm{m}$ ) were preincubated for $20 \mathrm{~min}$ in 10\% BSA in $0.1 \mathrm{M}$ PBS (PBS/BSA) and incubated with the primary antibodies diluted in PBS/BSA overnight at $4^{\circ} \mathrm{C}$. MBP antibody (dilution, 1:500) was used to identify the myelin sheath surrounding the axons with one of the following antibodies: Wnt1 (dilution, 1:50), LRP6 (dilution, 1:100), GSK3 $\beta$ (dilution, 1:50), and $\beta$-catenin (dilution, 1:500). Sections were imaged using a confocal microscope (LSM510; Carl Zeiss) with a $63 \times$ (NA 1.2) lens, and sequential excitation was performed with laser lines $488 \mathrm{~nm}$ (Ar.ion laser), $543 \mathrm{~nm}$ (HeNe laser), and $633 \mathrm{~nm}$ (HeNe laser).

Chromatin immunoprecipitation. MSC80 cells treated with Wnt1 for $4 \mathrm{~h}$ were fixed with $1 \%$ formaldehyde added to the medium for $10 \mathrm{~min}$, scraped, and collected by centrifugation. Cells were resuspended in 300 $\mu \mathrm{l} / \mathrm{ml}$ lysis buffer [ $5 \mathrm{~mm}$ piperazine- $N, N^{\prime}$-bis(2-ethanosulfonic acid), $\mathrm{pH} 8.0,85 \mathrm{~mm} \mathrm{KCl}, 0.5 \% \mathrm{NP}-40$ ] with a mixture of protease inhibitors (Roche). Cells were pelleted by centrifugation and resuspended in $300 \mu \mathrm{l}$ of $1 \%$ SDS, $10 \mathrm{~mm}$ EDTA, and $50 \mathrm{~mm}$ Tris- $\mathrm{HCl}, \mathrm{pH} 8.0$, containing protease inhibitors. After incubation on ice for $10 \mathrm{~min}$, they were sonicated six times for $30 \mathrm{~s}$ using Bioruptor (Diagenode). Lysates were then cleared by centrifugation, and the concentration of DNA was determined. Equal amounts of DNA were diluted 10 times in dilution buffer (0.01\% SDS, $1 \%$ Triton X-100, 1.2 mm EDTA, 16.7 mm Tris-HCl, $\mathrm{pH} 8.1$, $167 \mathrm{~mm} \mathrm{NaCl}$ ). The chromatin solution was precleared for $1 \mathrm{~h}$ at $4^{\circ} \mathrm{C}$ on protein G-agarose/salmon sperm DNA beads (Millipore). After brief centrifugation and removal of the beads, DNA was incubated overnight at $4^{\circ} \mathrm{C}$ on a rotating wheel with $1 \mu \mathrm{g}$ of either $\beta$-catenin antibody or nonrelevant antibody (anti-C23). Immune complexes were collected on protein G-agarose/salmon sperm DNA beads (Millipore). Beads were washed sequentially in TSE $(0.1 \%$ SDS, $1 \%$ Triton X-100, 2 mM EDTA, $20 \mathrm{~mm}$ Tris-HCl, pH 8.1) with $150 \mathrm{~mm} \mathrm{NaCl}$, TSE with $500 \mathrm{~mm} \mathrm{NaCl}$, buffer A ( $0.25 \mathrm{~m} \mathrm{LiCl}, 1 \% \mathrm{NP}-40,1 \%$ deoxycholate, 1 mм EDTA, $10 \mathrm{~mm}$ Tris-HCl, $\mathrm{pH}$ 8.1), and twice with Tris-EDTA and eluted with $200 \mu \mathrm{l}$ of $1 \% \mathrm{SDS}$ and $0.1 \mathrm{M} \mathrm{NaHCO}_{3}$. Cross-links were reversed by heating at $65^{\circ} \mathrm{C}$ for $4 \mathrm{~h}$ after adding $\mathrm{NaCl}$ to $200 \mathrm{~mm}$ final concentration. After treatment with proteinase $\mathrm{K}(50 \mu \mathrm{g} / \mathrm{ml})$ for $1 \mathrm{~h}$ at $37^{\circ} \mathrm{C}$, DNA was purified using the Geneclean Turbo kit (Q-Biogene). RT-PCR analysis of inputs or immunoprecipitated DNAs was performed.

Embryo care. Embryos were staged and cared for according to standard protocols. Several stable transgenic fish lines were used: (1) foxd3::GFP, selectively expressing the green fluorescent protein (GFP) in myelinating Schwann cells under the control of the zFoxD3/fkd6 promoter (Gilmour et al., 2002); (2) $\Delta$ TCF3 (hsp70:TCF-GFP), expressing an N-terminally truncated TCF3, a dominant repressor of Wnt-mediated transcription, and the GFP marker under the control of the zebrafish hsp70 promoter (Lewis et al., 2004); (3) HuC::GFP, specifically expressing GFP in neurons under the control of components of the HuC gene promoter (Park et al., 2000); and (4) olig2::EGFP, specifically expressing the enhanced green fluorescent protein (EGFP) in oligodendrocytes (H. Li, unpublished observations).

Heat-shock activation of transgenes. Transgenic $\Delta$ TCF3 embryos were heat shocked at either $48 \mathrm{~h}$ postfertilization (hpf) or $3 \mathrm{~d}$ postfertilization (dpf) for $1 \mathrm{~h}$ at $37^{\circ} \mathrm{C}$. Embryos were sorted out after nuclear GFP expression.

In situ hybridization. In situ hybridization was performed following standard protocols by using previously described MPZ, PLP, and MBP probes (Kazakova et al., 2006).

Immunohistochemistry. For immunostaining, embryos were fixed in $4 \%$ paraformaldehyde and stained as whole mounts. Anti-acetylated tubulin antibody was used at a dilution of 1:1000. Anti-phosphohistone H3 was used at a dilution of 1:200. Primary antibodies were detected with appropriate secondary antibodies conjugated to either Alexa 488 or Alexa 568 at a 1:200 dilution.

Electron microscopy. At $4 \mathrm{dpf}$ and $6 \mathrm{hpf}$, embryos were fixed in $2 \%$ paraformaldehyde and $2 \%$ gluteraldehyde in $0.1 \mathrm{~m}$ sodium cacodylate buffer, $\mathrm{pH}$ 7.3. Following postfixation in cacodylate-buffered $1 \% \mathrm{w} / \mathrm{v}$ osmium tetraoxide $\left(\mathrm{OsO}_{4}\right.$; Johnson-Matthey), the tissue was dehydrated and embedded in medium Agar 100 epoxy resin (Agar Scientific). Ultrathin sections $(80-90 \mathrm{~nm})$ were taken in the region of $1 \mathrm{~mm}( \pm 0.5 \mathrm{~mm})$ anterior to the end of the yolk sack extension. Sections were contrasted with saturated uranyl acetate solution and lead citrate and were examined and photographed using a 1010 electron microscope (JEOL) and digital camera (Gatan).

Axon counting and analysis. Montages of electron micrographs of the whole posterior lateral line nerves were made using Adobe Photoshop ( $n=11$ nerves from 6 embryos for the control group and $n=12$ nerves from 6 embryos for the $\Delta \mathrm{TCF} 3$ group). Total numbers of unmyelinated axons, axons ensheathed with compacted Schwann cell lamellae, and axons ensheathed with uncompacted Schwann cell lamellae were counted. Axons were defined as ensheathed if they had a 1:1 ratio with Schwann cell lamellae and had at least 1.5 wraps; if any part of the lamellae ensheathing the axon showed compaction, then the axon was counted as ensheathed with compact myelin. To allow for differences in section level between individuals, percentages of axons in the three groups were calculated, and differences were tested for significance using the Student's $t$ test with Welch's correction taking $p<0.01$ as significant.

Statistical analysis. Unless specified otherwise, results are expressed as means \pm SEM. The means of two treatment groups were compared by the two-tailed Student's $t$ test. For multiple group comparisons, one-way ANOVA followed by Tukey's test was used. ${ }^{*} p<0.05$ was considered statistically significant.

\section{Results}

$\mathrm{Wnt} / \boldsymbol{\beta}$-catenin signaling components are expressed in Schwann cells and peripheral myelin

We showed that the major components of the canonical Wnt pathway (Wnt1, LRP6, DSH, GSK3 $\beta, \beta$-catenin, and TCF/LEF1) are expressed in the mouse MSC80 Schwann cell line (Fig. 1). Wnt1 and LRP6 showed a cytoplasmic and/or membrane local- 
ization, DSH and GSK3 $\beta$ were cytoplasmic, and $\beta$-catenin was located in the cytoplasm, the nucleus, and the membrane. As expected, LEF1 or TCF3/4 was strictly nuclear. We have also confirmed the presence of the Wnt components in primary cultures of Schwann cells isolated from neonatal sciatic nerves (supplemental Fig. $1 b$, available at www.jneurosci.org as supplemental material).

We examined the expression of main Wnt ligands (Wnt1, Wnt3, Wnt3a, and Wnt7a) by qRT-PCR in the developing mouse sciatic nerve (Fig. 2A). Their mRNA levels accompanied the expression of the peripheral myelin genes MPZ and PMP22, and they were highest at P20. We have also analyzed the expression of major canonical Wnt pathway components at the same time points. LRP6, DSH1, DSH2, DSH3, TCF1, TCF3, and TCF4 expression was increased at P6 compared with P0 and then decreased at P20. LEF1 expression was maintained at the same levels at P6 and P20, whereas $\beta$-catenin transcript levels did not vary along the myelination process. We then performed immunohistochemical analysis of Wnt1 and of the main intracellular components of the $\mathrm{Wnt} / \beta$-catenin pathway in the mouse sciatic nerve at P7 and P21. At both stages, Wnt1, LRP6, GSK3 $\beta$, and $\beta$-catenin were located, among other structures, in the myelin sheaths and colocalized with MBP immunoreactivity (Fig. $2 B$; see also supplemental Fig. $1 a$, available at www.jneurosci.org as supplemental material). We quantified the relative expression of each TCF/LEF family member in the sciatic nerves of adult mice and in primary Schwann cells. As shown in supplemental Figure $1 b$ (available at www.jneurosci.org as supplemental material), TCF3 was the most expressed TCF/LEF family member in the sciatic nerve and primary Schwann cells. The other TCF/LEF members were all present, but less abundantly. The relative differences in TCF/LEF family member expression between P20 and adult sciatic nerves is most probably attributable to a developmental change. Thus, Wnt ligand and the major components of the Wnt/ $\beta$-catenin signaling pathway are present in the myelin sheaths of developing peripheral nerves and in Schwann cells.

\section{$\mathrm{Wnt} / \boldsymbol{\beta}$-catenin pathway is involved in the regulation of myelin gene promoter activity in Schwann cells}

To determine whether the canonical Wnt signaling pathway is activated in MSC80 cells, we selectively inhibited the expression of LRP6, DSH, $\beta$-catenin, or TCF/LEF. The Schwann cell line was transiently transfected with a TCF/LEF reporter construct (TOPFlash-luciferase), a positive control reading $\mathrm{Wnt} / \beta$-catenin signaling activity, or with either MPZ or PMP22 promoterluciferase constructs (MPZ-luc or PMP22-luc). Cotransfecting a dominant-negative expression vector either of LRP6 (LRP6 $\Delta \mathrm{C}$ ), which inhibits Wnt signaling at the level of its receptors (Tamai et al., 2000), or of DSH (DSH-dn) strongly inhibited the activity of the TOP-Flash reporter, showing the efficacy of the dominant- negative mutants and demonstrating the functionality of the canonical Wnt pathway in MSC80 cells (Fig. 3a,b). LRP6 $\Delta$ C and DSH-dn also strongly inhibited the MPZ-luc and PMP22-luc reporter constructs. These findings suggest a role for LRP6 and $\mathrm{DSH}$ in the activation of myelin protein gene promoters.

The involvement of $\beta$-catenin in MPZ and PMP22 promoter activity in MSC80 cells was demonstrated by applying two strategies: either the overexpression of the active nuclear form of $\beta$-catenin or the knockdown of $\beta$-catenin expression by a specific siRNA. The efficacy of the siRNA was verified by $\beta$-catenin immunostaining (data not shown). Overexpression of nuclear $\beta$-catenin increased by fivefold the activity of the TOP-Flash and MPZ promoters and by threefold the PMP22 promoter activity. On the contrary, knocking down endogenous $\beta$-catenin expression resulted in an $80 \%$ reduction in TOP-Flash promoter activity and a $50-60 \%$ reduction in MPZ and PMP22 promoter activities (Fig. 3c).

We then evaluated the effect of the Wnt/ $\beta$-catenin nuclear effectors TCF1, LEF1, TCF3, or TCF4 by knocking down their expression in the Schwann cell line with specific siRNA. The efficacy of each siRNA directed against a specific TCF was analyzed by qRT-PCR. Each siRNA significantly inhibited the cognate TCF without affecting the expression of the other TCF/LEF (supplemental Fig. $2 a$, available at www.jneurosci.org as supplemental material). The siRNA directed against each of the TCF/LEF resulted in a remarkable inhibition of TOP-Flash reporter activity 
A
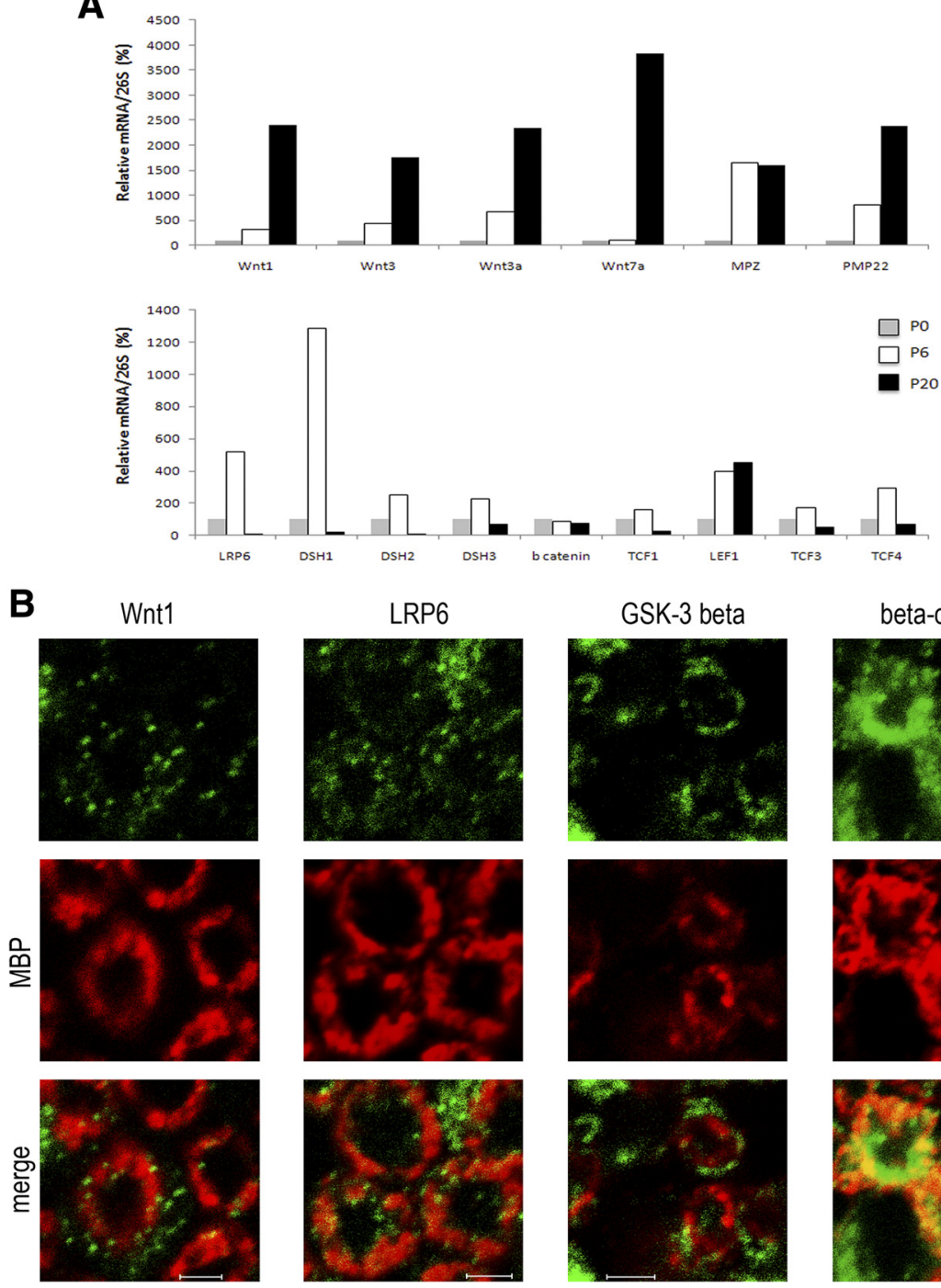

Figure 2. Expression and localization of Wnt components during sciatic nerve development. $\boldsymbol{A}$, Total RNA from sciatic nerves of mice at different developmental stages (P0, P6, and P20) was prepared. qRT-PCR experiments were performed with primers specifically recognizing Wnt ligands (Wnt1, Wnt3, Wnt3a, Wnt7a), Wnt components (LRP6, DSH1, DSH2, DSH3, B catenin, TCF1, LEF1, TCF3, TCF4), or sequences of the peripheral myelin protein genes MPZ or PMP22. We used 26S proteasomal RNA (26S) to normalize the $q R T-P C R$ data as the expression of 26S RNA was constant at P0, P6, and P21. We established a ratio for each RNA (Wnt1, Wnt3, Wnt3a, Wnt7a, MPZ, PMP22) relative to 265 rRNA at P0 $(n=3)$. $\boldsymbol{B}$, The spatial expression patterns of various members of the Wnt signaling pathway in sciatic nerve sections of mice aged $7 \mathrm{~d}$. Myelin sheaths were stained with anti-MBP antibody (in red), and Wnt components were localized with antibodies against Wnt1, LRP6, GSK3 $\beta$, and $\beta$-catenin (in green). The slides were analyzed with a confocal microscope. This experiment was repeated twice, and a typical experiment is presented here. The images shown represent $1 \mu \mathrm{m}$ of confocal $Z$ sectioning. Scale bars, $2 \mu \mathrm{m}$.

(Fig. 3d). Likewise, TCF3 or TCF4 knockdown inhibited MPZ promoter activity by $80 \%$, whereas blocking TCF1 and LEF1 expression exerted a $50 \%$ inhibition (Fig. $3 d$ ). The knockdown of any of the four TCFs resulted in a 50\% decrease in PMP22 promoter activity (Fig. $3 d$ ). Thus, the major components of the Wnt/ $\beta$-catenin signaling pathway, upstream and downstream of $\beta$-catenin, are involved in peripheral myelin gene expression.

\section{Exogenous Wnt ligand increases the expression of myelin} protein gene expression in Schwann cells

We then determined whether exogenous Wnt may further increase peripheral myelin gene expression. We tested the effect of the Wnt ligands whose expression was enhanced during the myelination process (Fig. 2A) on MPZ and PMP22 gene expression.
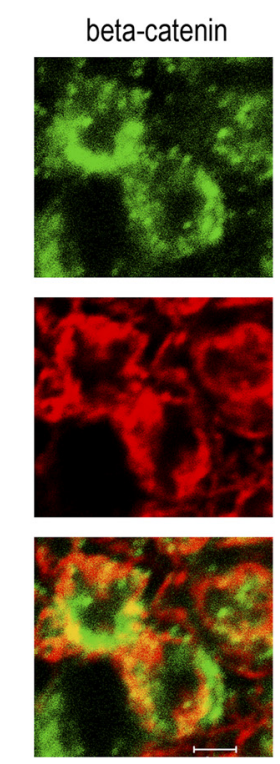

First, MSC80 cells were incubated for $24 \mathrm{~h}$ with conditioned media containing Wnt1, Wnt3, Wnt3a, or Wnt7a. In all cases, the expression of a Wnt target gene (connexin 43) was activated in MSC80 cells indicating that the conditioned culture media contain Wnt ligands (data not shown). The expression of myelin genes (MPZ and PMP22) was analyzed by qRTPCR. Wnt1, Wnt3, Wnt 3a, and Wnt7a activated MPZ by 2- or 3-fold, whereas Wnt1, Wnt3, and Wnt3a stimulated PMP22 (1.5- and 2-fold) in MSC80 cells. Wnt7a did not enhance PMP22 (Fig. 4a).

We then focused our work on Wnt1. Primary Schwann cells or MSC80 cells were incubated with recombinant Wnt1 for $1 \mathrm{~h}$ and harvested immediately after. As expected, Wnt1 significantly increases both MPZ and PMP22 transcripts at $1 \mathrm{~h}$ in primary Schwann cells and in MSC80 cells (Fig. 4b). Western blot analysis demonstrated a rapid (within $1 \mathrm{~h}$ ) and marked increase in MPZ, PMP22, and $\beta$-catenin proteins in MSC80 cells, which lasted for up to $24 \mathrm{~h}$ of treatment with Wntl (Fig. 4c). Most important, treatment of MSC80 with Wnt1 modified neither the expression nor the phosphorylation state of Akt (data not shown).

To pinpoint the effects of Wnt1 treatment at the level of the mouse MPZ and PMP22 gene promoters, we located two potential TCF/LEF response elements at the level of the MPZ promoter (Fig. $4 d$ ). Chromatin immunoprecipitation (ChIP) analysis demonstrated that Wnt treatment enhanced twofold $\beta$-catenin recruitment by the TCF/LEF response elements located at $-8487 /-8471 \mathrm{bp}$, but not by the second TCF/LEF response element $(-5487 /$ -5461) (Fig. 4e). A potential TCF/LEF response element was also identified at position $+107 /+124$ of the PMP22 promoter, and ChIP analysis revealed that Wntl treatment also increased the recruitment of $\beta$-catenin at this site (Fig. $4 d, e$ ). These data show that Wnt ligand increases MPZ and PMP22 mRNA and protein levels in the Schwann cell line via TCF transactivation.

\section{$\mathrm{Wnt} / \boldsymbol{\beta}$-catenin pathway also drives myelin gene expression in oligodendrocytes}

An important issue is whether Wnt signaling also activates myelin protein gene expression in oligodendrocytes, where the presence of Wnt/ $\beta$-catenin pathway components has been reported previously and exerted a delay in the differentiation of OPCs (Fancy et al., 2009; Feigenson et al., 2009; Ye et al., 2009). We performed experiments with primary cultures enriched with either OPCs or oligodendrocytes. These cultures were incubated with Wntl or Wnt3a. Wnt1 and Wnt3a did not stimulate proteolipid protein gene $(p l p)$ expression in OPC-enriched cultures (data not shown). Interestingly, in oligodendrocyte-enriched cultures, Wnt1 
a

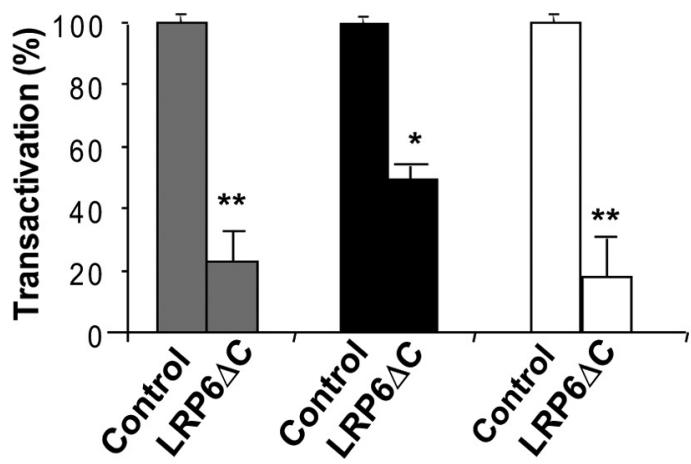

b

TOP-FLASH MPZ

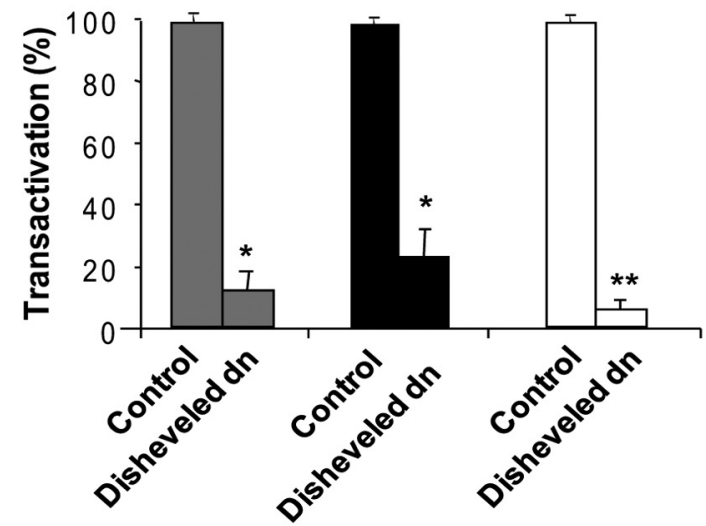

C

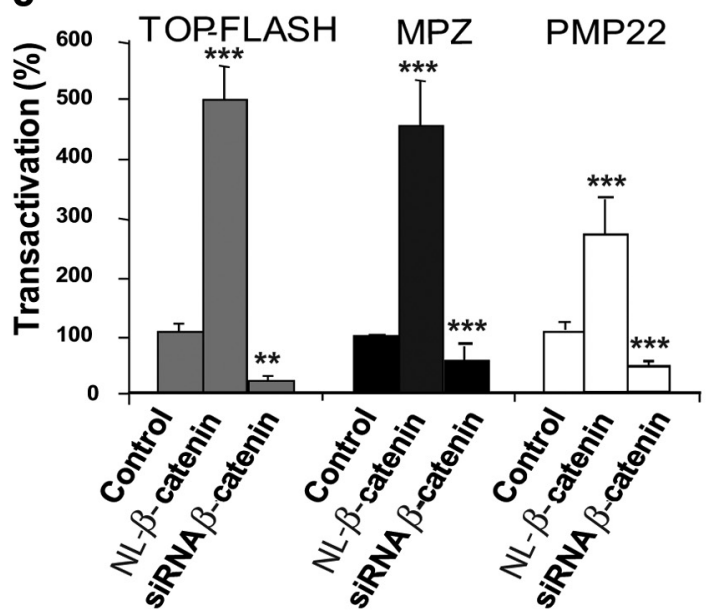

d

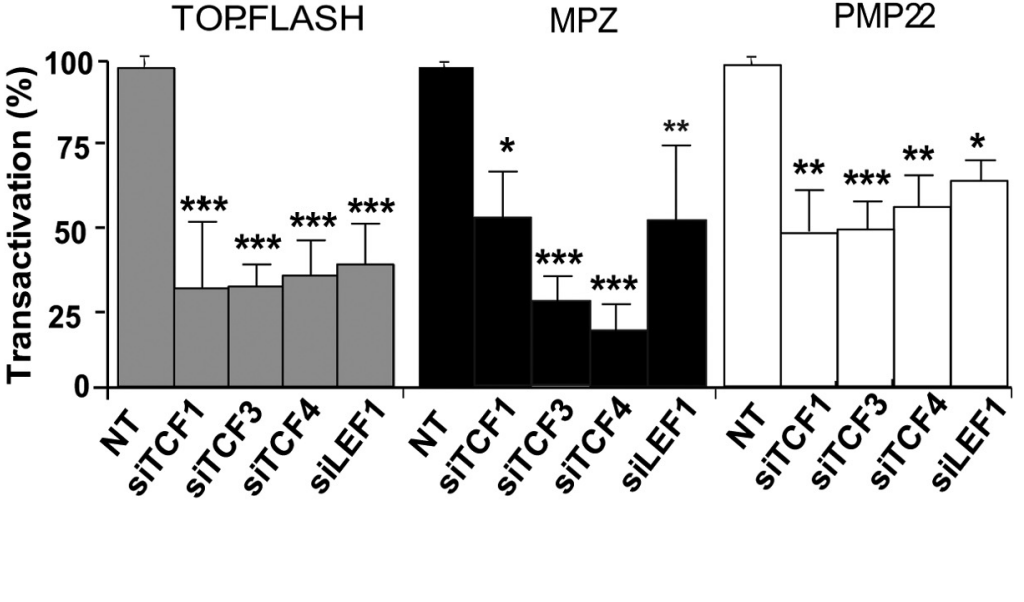

MPZ
PMP22

Figure 3. Involvement of the Wnt signaling pathway in basal MPZ and PMP22 promoter activity. $\boldsymbol{a}-\boldsymbol{c}$, MSC 80 cells were transiently transfected either with peripheral myelin protein gene promoter-luciferase constructs (MPZ-luc or PMP22-luc) or the TOP-Flash-Luc reporter of Wnt/ $\beta$-catenin signaling together with the following: $\boldsymbol{a}$, a dominant-negative expression vector of LRP6 $(\mathrm{LRP} 6 \Delta \mathrm{C}) ; \boldsymbol{b}$, a dominant-negative expression vector of DSH (DSH-dn); $\boldsymbol{c}$, either a constitutive NL- $\beta$-catenin expression vector or an siRNA directed against $\beta$-catenin. Twenty-four hours after transfection, $\beta$-galactosidase and luciferase activities were analyzed. Results represent the means \pm SEM of at least four independent experiments performed in duplicate. ${ }^{*} p<0.05$; ${ }^{* *} p<0.01$; ${ }^{* * *} p<0.001$, compared with control. $\boldsymbol{d}$, MSC80 cells were transiently transfected with MPZ-Luc, PMP22-Luc, or TOP-Flash-Luc plasmids and with siRNA directed against the four TCFs or NT. Twenty-four hours after transfection, $\beta$-galactosidase and luciferase activities were analyzed. Results represent means \pm SEM of eight independent experiments performed in duplicate. ${ }^{*} p<0.05$; ${ }^{* *} p<0.01 ;{ }^{* * *} p<0.001$, by Tukey's post hoc test after one-way ANOVA, compared with the NT control.

and Wnt3a stimulated by 3.5-fold and 2-fold, respectively, the expression of $p l p$, suggesting a differential role of the Wnt pathway during oligodendroglial development (Fig. 5a).

We also investigated in the mouse oligodendrocyte cell line $158 \mathrm{~N}$ the implication of different components of the Wnt $\beta$-catenin pathway in the activation of the plp promoter. The oligodendrocyte cell line $158 \mathrm{~N}$ expresses properties of oligodendrocytes, including specific markers, myelin proteins and myelin lipids. These cells thus provide a powerful model to explore oligodendrocyte functions. First, we showed that adding recombinant Wnt1, but not Wnt3a, to the culture medium stimulates $p l p$ expression (Fig. 5a). We then cotransfected the oligodendrocyte cell line with the TOP-Flashluciferase or PLP promoter-luciferase (PLP-luc) constructs with or without LRP6 $\Delta \mathrm{C}$ or DSH-dn. As in MSC80, both dominantnegative expression vectors strongly inhibited the activity of the TOP-Flash reporter, demonstrating the functionality of LRP6 and DSH in the oligodendrocyte cell line (Fig. $5 b, c$ ). Moreover, LPR6 $\Delta \mathrm{C}$ and DSH-dn inhibited PLP promoter activity, indicating their critical involvement in PLP expression (Fig. 5b,c).

Consistent with an important role of the $\mathrm{Wnt} / \beta$-catenin pathway in oligodendrocyte myelination, knocking down $\beta$-catenin with siRNA inhibited TOP-Flash expression by $40 \%$ and PLP promoter activity by $70 \%$ (Fig. $5 d$ ). Conversely, overexpression of nuclear-localized $\beta$-catenin enhanced PLP promoter activity by 2.3 -fold (Fig. $5 d$ ). Downstream of $\beta$-catenin, all four TCF/LEF transcription factors are also expressed, but at different levels (supplemental Fig. 1b, available at www.jneurosci.org as supplemental material), in both $158 \mathrm{~N}$ cells and oligodendrocytes, and their expression could be strongly inhibited by siRNA (supplemental Fig. $2 b$, available at www.jneurosci.org as supplemental material). The siRNA directed against each of the TCF/LEFs resulted in a remarkable inhibition of TOP-Flash reporter activity. Likewise, the knockdown of each TCF/LEF inhibited the activity of the PLP promoter by $60-70 \%$, pointing to an important role of the transcription factors in PLP gene expression (Fig. 5e). These results demonstrate that $\mathrm{Wnt} / \beta$-catenin signaling components also drive myelin gene expression in oligodendrocytes.

Interaction between $\boldsymbol{\beta}$-catenin and TCF3 is required for Schwann cell myelination in vivo

To demonstrate in vivo the significance of Wnt/ $\beta$-catenin signaling during developmental myelination, we used the zebrafish model, which allows the downregulation of specific components of the Wnt/ $\beta$-catenin pathway at the onset of myelination. To 
M PZ

a

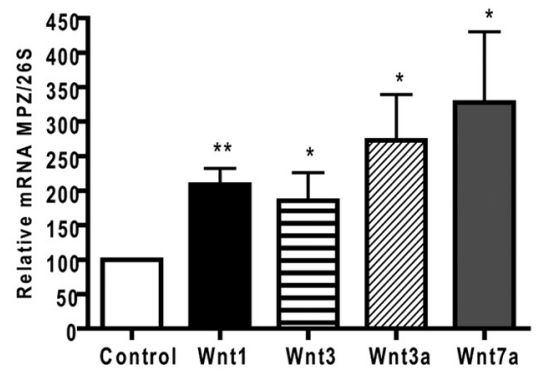

b
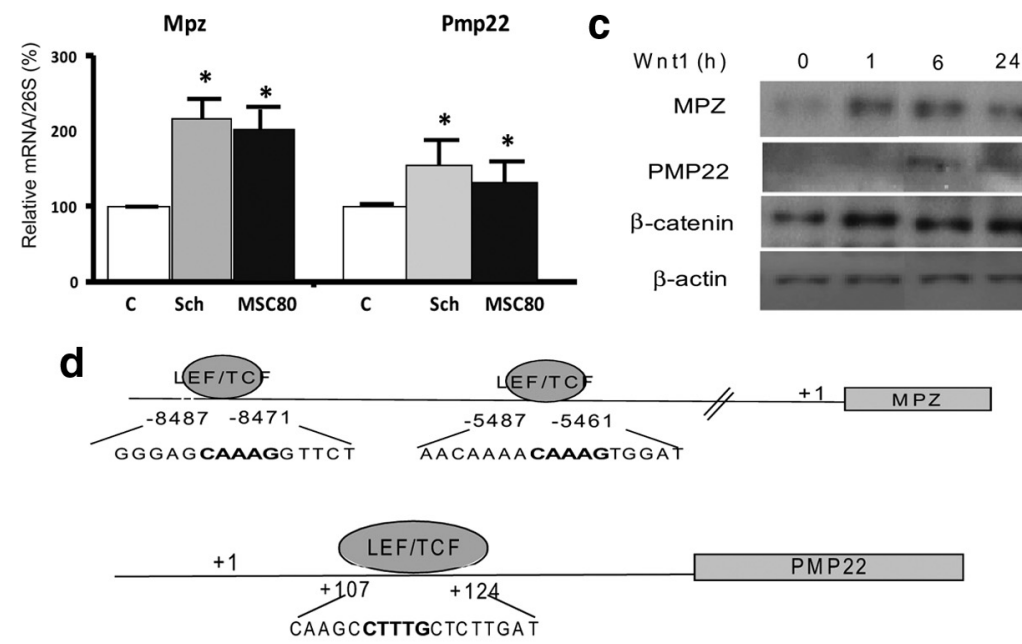

e

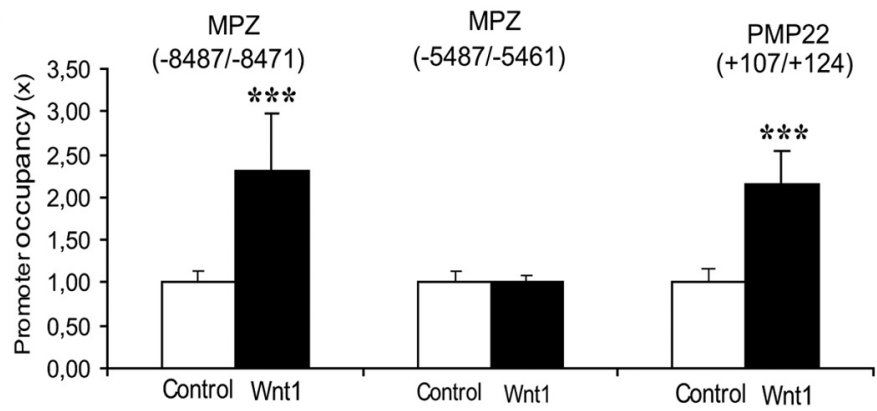

Figure 4. Effect of Wnt ligands on MPZ and PMP22 expression in Schwann cells. $\boldsymbol{a}$, Conditioned media were prepared from MSC80 cells transfected with Wnt1, Wnt3, Wnt3a, or Wnt7a expression vectors. Forty-eight hours after the transfection, the culture media were collected and put on fresh MSC 80 cells for $24 \mathrm{~h}$. Total RNA was extracted, and qRT-PCR experiments were performed using primers recognizing MPZ or PMP22. The RT-PCR was normalized using $265 \mathrm{SNA} .{ }^{*} p<0.05 ;{ }^{* *} p<0.01$, by Tukey's post hoc test after one-way ANOVA, compared with control $(n=7)$. $\boldsymbol{b}$, Primary Schwann cells $(n=4)$ or the MSC80 cell line $(n=8)$ were incubated with Wnt 1 ligand $(5 \mathrm{ng} / \mathrm{ml})$ for $1 \mathrm{~h}$. Total RNA was extracted, and qRT-PCR experiments were performed using primers recognizing MPZ or PMP22. The RT-PCR was normalized using 26S RNA. ${ }^{*} p<0.05$, by Student's $t$ test, compared with control. $c$, MSC80 cells were incubated with recombinant Wnt $1(5 \mathrm{ng} / \mathrm{ml})$ for 1,6 , or $24 \mathrm{~h}$. Western blots were performed using anti-MPZ, anti-PMP22, or anti- $\beta$-catenin antibodies to verify their expression. $\beta$-Actin was used to normalize the Western blots. These results were reproduced in three independent experiments, and a typical experiment is presented. $\boldsymbol{d}$, Putative TCF/LEF binding sites located in MPZ or PMP22 genes were identified with MatInspector software (Genomatix). $\boldsymbol{e}$, ChiP assays were performed on Schwann cell extracts treated or not with Wnt- 1 for $4 \mathrm{~h}$, by using $(23$ antibody as a nonrelevant antibody or using $\beta$-catenin antibody. qRT-PCR was performed with primers recognizing putative TCF/LEF binding sites located in MPZ or PMP22 genes. Results are the mean of at least five independent experiments. ${ }^{* * *} p<0.001$, by Tukey's post hoc test after one-way ANOVA, compared with control.

assess whether the transcriptional complex $\beta$-catenin/TCF is necessary for myelin gene expression in the Schwann cells of zebrafish embryos, we made use of the inducible transgenic line $\Delta \mathrm{TCF} 3$, which expresses a truncated form of TCF3 under the control of a heat shock promoter (hsp70; hsp70:TCF-GFP), preventing $\beta$-catenin from binding to TCF3 after a heat shock (Lewis et al., 2004). This transgenic line also expresses the GFP marker, which can be seen in cell nuclei within $1 \mathrm{~h}$ after a heat shock. Embryos were heat shocked at $2 \mathrm{dpf}$, corresponding to the onset of zebrafish myelination, whereby oligodendrocytes and Schwann cells start expressing myelin genes (Brosamle and Halpern, 2002; Lyons et al., 2005). mbp mRNA expression, a widely used marker for the onset of myelination in zebrafish (Monk and Talbot, 2009), was analyzed at 4 or $5 \mathrm{dpf}$ by in situ hybridization at the level of the peripheral lateral line (PLLn), where axons are solely myelinated by Schwann cells.

In control embryos (either wild-type or heat-shocked non-GFP), mbp mRNA was strongly expressed in PLLn Schwann cells at $5 \mathrm{dpf}$ (Fig. $6 a$ ). However, after heat shock, $m b p$ expression was either strongly reduced (Fig. $6 b)$ or even absent $(n=25$ of 28) (Fig. 6c). Levels of $m b p$ expression negatively correlated with the efficiency of inactivation, assessed by GFP expression (data not shown). To validate the in situ analysis and the specificity of the dysmyelinating phenotype, we also analyzed $m b p$ expression by qRT-PCR at $4 \mathrm{dpf}$. We found a significant $40 \%$ reduction in $m b p$ mRNA in heat-shocked embryos compared with controls, reflecting the mean reduction of embryos with complete or partial inhibition of TCF3/ $\beta$-catenin interaction (supplemental Fig. $3 a$, available at www.jneurosci.org as supplemental material). These results indicate an essential role of $\beta$-catenin/TCF3 interaction in regulating $m b p$ expression and thus a likely role in PNS myelination.

The deficiency in myelin can be mainly attributed to the lack in myelin gene expression but not to defects in axonal growth, because when heat-shocked embryos were labeled with acetylated tubulin, no changes in axonal labeling were observed between control (Fig. $6 d$ ) and $\Delta$ TCF3 embryos (Fig. $6 e$ ) at 4 dpf. We also examined Schwann cell survival after heat shock by making use of the stable transgenic line foxd3::GFP (Gilmour et al., 2002), expressing GFP in myelinating Schwann cells. No differences in glial cell number and distribution were observed between controls (Fig. $6 f$ ) and $\Delta$ TCF3 embryos (Fig. $6 g$ ). These data show that disrupting the interaction between $\beta$-catenin and TCF3 results in reduced $m b p$ expression, without affecting axons or Schwann cells.

To assess whether $\beta$-catenin/TCF3 interaction continues to be required after the initiation of Schwann cell myelination, we heat shocked $\triangle \mathrm{TCF} 3$ embryos either at 2 or $3 \mathrm{dpf}$ and examined $m b p$ expression $2 \mathrm{~d}$ later. Results confirmed that $m b p$ expression is strongly reduced when $\beta$-catenin/TCF3 interaction is disrupted at $2 \mathrm{dpf}$. In contrast, in $\triangle \mathrm{TCF} 3$ embryos heat shocked at $3 \mathrm{dpf}$, 

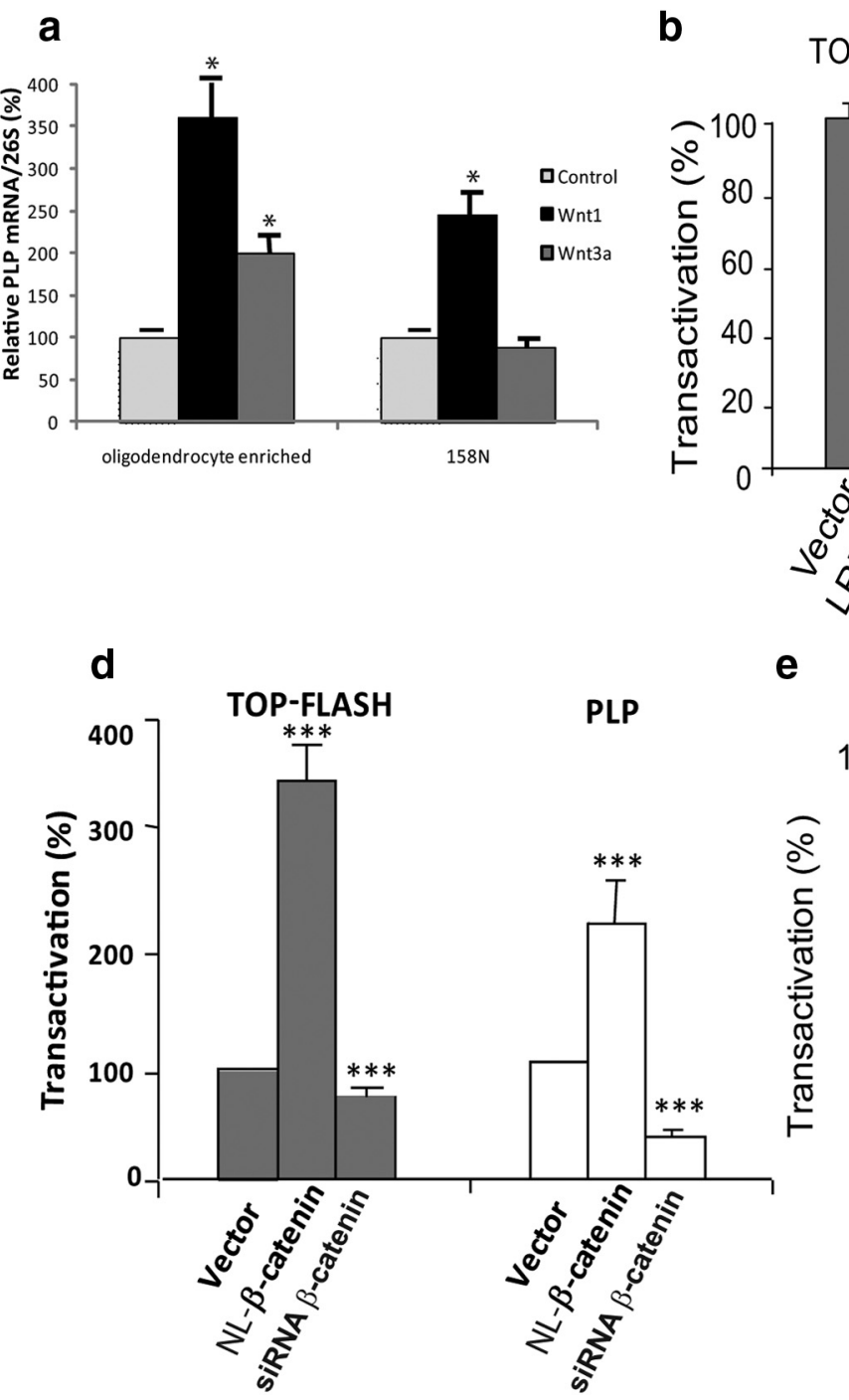

b

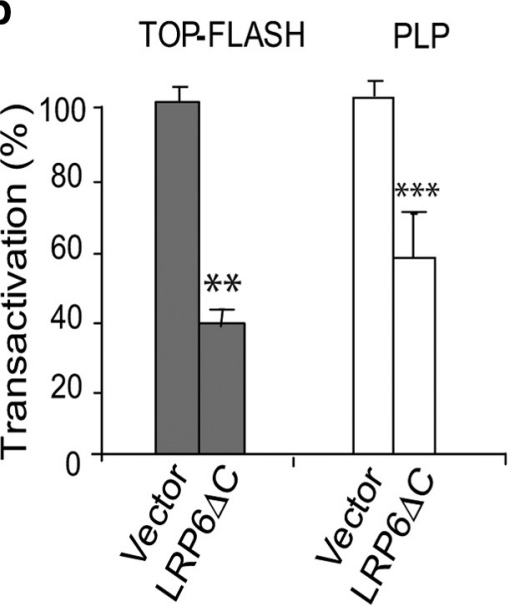

C TOP-FLASH PLP

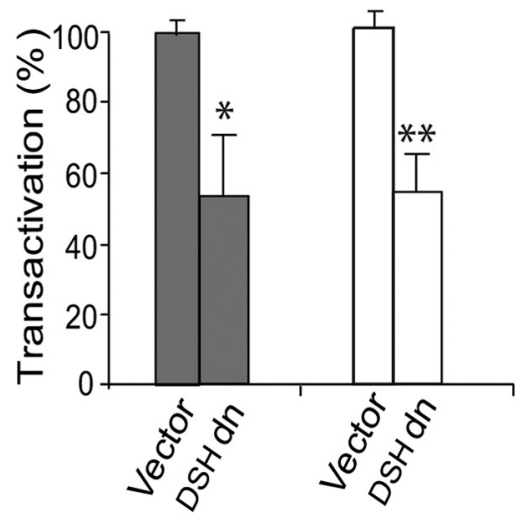

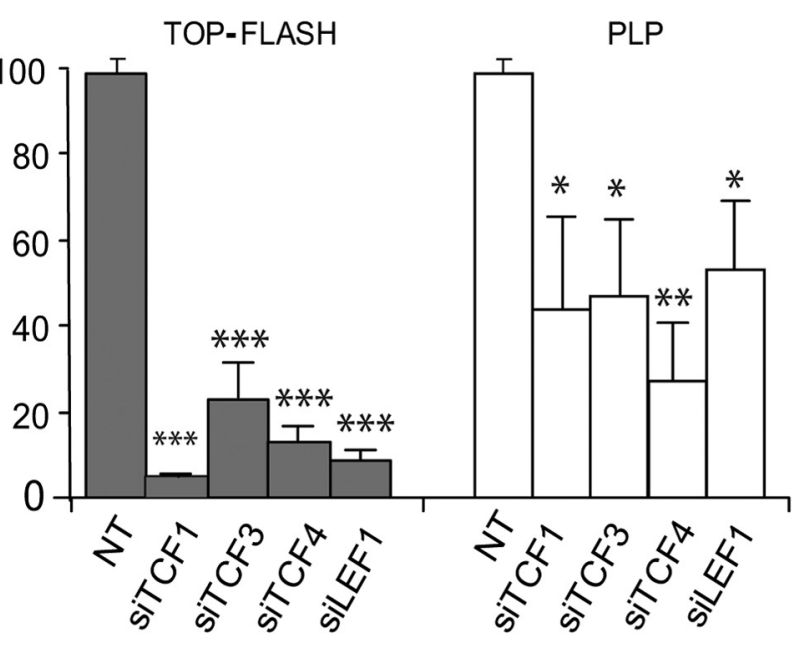

Figure 5. Role of Wnt components in the basal expression of PLP in oligodendrocytes. $\boldsymbol{a}$, Primary cultures enriched with oligodendrocytes or $158 \mathrm{~N}$ oligodendrocyte cell line were incubated with Wnt1 $(5 \mathrm{ng} / \mathrm{ml})$ or Wnt3a $(100 \mathrm{ng} / \mathrm{ml})$ for $24 \mathrm{~h}$. Total RNA was extracted, and qRT-PCR experiments were performed using primers recognizing PLP. The RT-PCR was normalized using 265 RNA. * $p<$ 0.05 , by Tukey's post hoc test after one-way ANOVA, compared with control $(n=5) \cdot \boldsymbol{b}-\boldsymbol{d}, 158 \mathrm{~N}$ oligodendrocytes were transiently transfected with $0.2 \mu \mathrm{g}$ of the PLP promoter-luciferase construct (PLP-Luc) or the TOP-Flash-Luc reporter of Wnt/ $\beta$-catenin signaling, $0.1 \mu \mathrm{g}$ of pRSV- $\beta$-galactosidase plasmids, with or without a dominant-negative expression vector of LRP6 (LRP6 $\Delta C$; $\boldsymbol{b})$, a dominant-negative expression vector of DSH (DSH-dn; $\boldsymbol{c}$ ), and either a constitutive nuclear-localized $\beta$-catenin (NL- $\beta$-catenin) expression vector or an siRNA directed against $\beta$-catenin (d). Forty-eight hours after transfection, $\beta$-galactosidase and luciferase activities were analyzed. Results are expressed as the induction over the basal activity and represent the mean \pm SEM of at least four independent experiments performed in duplicate when compared with control.e, $158 \mathrm{~N}$ oligodendrocytes were transiently transfected with PLP-Luc or TOP-Flash-Luc plasmids and with siRNA directed against one of the four TCFs or NT as indicated. Forty-eight hours after transfection, $\beta$-galactosidase and luciferase activities were analyzed. Results are expressed as the induction over the basal activity and represent the mean \pm SEM of at least four independent experiments performed in duplicate. ${ }^{*} p<0.05 ;{ }^{* *} p<0.01 ;{ }^{* * *} p<0.001$, by Tukey's posthoc test after one-way ANOVA, compared with NT controls.

$m b p$ expression was not affected compared with controls (supplemental Fig. $3 b$, available at www.jneurosci.org as supplemental material). Thus, $\beta$-catenin/TCF3 interaction is primarily required before $3 \mathrm{dpf}$ for the onset of $m b p$ expression.

\section{$\mathrm{Wnt} / \boldsymbol{\beta}$ catenin pathway is required for $m b p$ expression in the PNS}

How did the dysmyelinating phenotype result from altered $\beta$-catenin/TCF3 interaction in zebrafish Schwann cells? In embryos injected with 250-300 pg of a dominant-negative construct of LRP6 (LRP6 $\Delta$ C), $m b p$ expression at the level of the PLLn was severely reduced in $67 \%$ of the LRP $6 \Delta \mathrm{C}$-injected embryos at 3 dpf (Fig. 6i) compared with controls (Fig. 6h). In this experiment, embryos were already analyzed at $3 \mathrm{dpf}$, as qRT-PCR analysis showed that the efficiency of the injected mRNA drops from $2 \mathrm{dpf}$ onward (data not shown).

The pattern of PLLn axons was not affected by the amount of LRP6 $\Delta$ C injected in HuC::GFP embryos, which specifically express GFP in neurons under the control of components of the $\mathrm{HuC}$ gene promoter (Park et al., 2000). Most LRP6 $\Delta \mathrm{C}$-injected HuC::GFP embryos had a normal PLLn (11 of 15 embryos) (Fig. $6 j, k)$. Moreover, the use of foxd3::GFP embryos demonstrated that the development of Schwann cells was not affected by the amount of LRP $6 \Delta \mathrm{C}$ injected. Indeed, $80 \%$ of the injected embryos $(n=10$ of 12$)$ showed a normal temporal development and survival of Schwann cells (Fig. 6l,m). Canonical Wnt signaling is required for cell proliferation (Megason and McMahon, 2002), and Schwann cell proliferation is essential for myelination (Lyons 

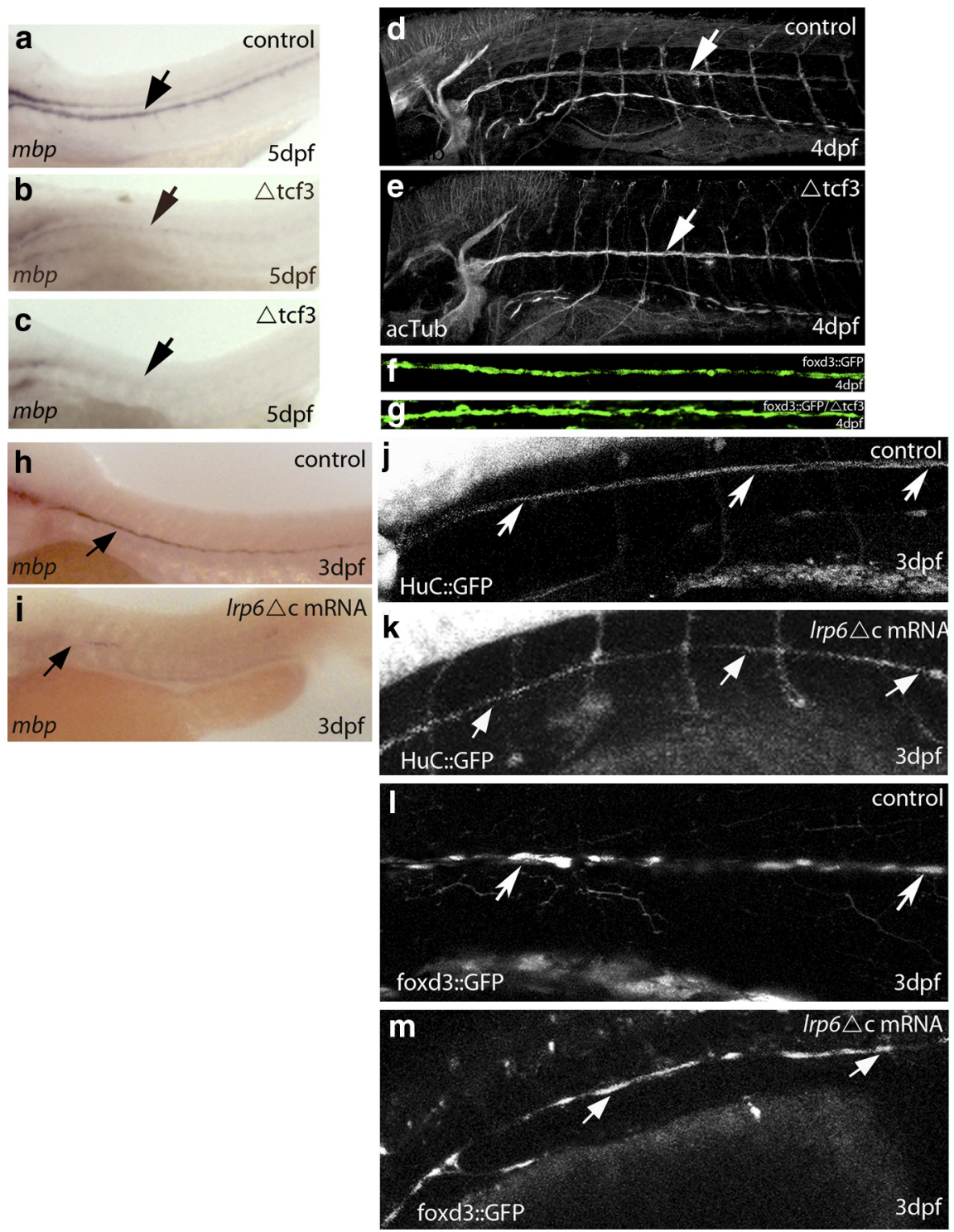

Figure 6. Analysis of Schwann cell myelination in $\triangle T$ TF3 zebrafish embryos and after LRP6 knockdown in the peripheral latera line. $\boldsymbol{a}$, Lateral view of $m b p$ RNA expression in a control embryo at $5 \mathrm{dpf}$. $m b p$-expressing cells are seen along the PLLn (arrow; $n=$ 60). $\boldsymbol{b}$, Lateral view of MBP RNA expression in $\triangle \mathrm{TCF} 3$ embryos at $5 \mathrm{dpf}$, heat shocked at $48 \mathrm{hpf}$. The arrow indicates mbp-expressing cells along the PLLn. $c$, Lateral view of mbp RNA expression in $\triangle T C F 3$ embryos showing a more severe phenotype (almost no mbp expression) at $5 \mathrm{dpf}$, heat shocked at $48 \mathrm{hpf}$. $\boldsymbol{d}$, Lateral view of acetylated tubulin-expressing axons of the PLLn (arrow) in control at $4 \mathrm{dpf}$. $\boldsymbol{e}$, Lateral view of acetylated tubulin-expressing axons of the PLLn (arrow) in a $\Delta T C F 3$ embryo at $4 \mathrm{dpf}$, heat shocked at 48 hpf. Axonal growth is similar to control ( $n=10$ per group). $\boldsymbol{f}$, $\boldsymbol{g}$, Confocal images of foxd3::GFP-expressing Schwann cells at $4 \mathrm{dpf}$ in control embryo $(\boldsymbol{f} ; n=10)$ and in $\Delta \mathrm{TCF} 3$ embryo $(\boldsymbol{g} ; n=18)$ heat shocked at 48 hpf. No significant differences were observed between controls and $\Delta \mathrm{TCF} 3$ embryos in Schwann cell distribution and survival. $\boldsymbol{h}$, Lateral view of $m b p$ RNA expression in control embryo at $3 \mathrm{dpf}$. The arrow indicates mbp-expressing cells along the PLLn $(n=40)$. $i$, Lateral view of mbp RNA expression in a LRP6 $\Delta$ C-injected embryo at $3 \mathrm{dpf}$. The arrow indicates mbp-expressing cells along the PLLn. mbp RNA expression is significantly reduced compared with control $(n=19 / 28)$. $\boldsymbol{j}$, Lateral view of a HuC::GFP embryo expressing GFP in neurons showing PLLn (arrows). $\boldsymbol{k}$, Embryo injected with LRP6 $\Delta C$. Axonal growth is similar to controls. $I$, Lateral view of foxd3::GFP embryo expressing GFP in Schwann cells (arrows). $m$, Embryo injected with LRP6 $\Delta C$.

et al., 2005). We thus asked whether LRP6 $\Delta \mathrm{C}$ might affect myelin gene expression in a proliferation-dependent manner. In foxd3::GFP embryos, mitotic PLLn Schwann cells were stained with anti-phospho-H3, a marker of proliferating cells. Injection of LRP $6 \Delta \mathrm{C}$ mRNA did not affect the number of proliferating Schwann cells at $3 \mathrm{dpf}(p>0.1, t=1.76$; controls: average, 26.75; $n=6$; LRP6 $\Delta$ C: average, $23.33 ; n=6)$. Together, our data suggest that the $\mathrm{Wnt} / \beta$-catenin pathway is essential for the onset of Schwann cell myelination and the expression of myelin genes, independently of axonal growth, Schwann cell migration, and proliferation.

\section{Interaction between $\beta$-catenin and TCF3 is required for peripheral myelin formation}

We examined the ultrastructure of PLLn nerves in $\triangle$ TCF3 embryos by transmission electron microscopy. Our previous results indicated that, although Schwann cells develop normally in heat-shocked $\Delta \mathrm{TCF} 3$ embryos at $2 \mathrm{dpf}$, they fail to express myelin genes, suggesting that they may be arrested at a promyelinating stage.

At $5 \mathrm{dpf}$, the multiple axons of the PLLn were surrounded by membrane wraps in both control and $\triangle \mathrm{TCF} 3$ embryos (Fig. $7 A-$ $D)$. Although there appeared to be fewer enwrapped axons in $\triangle \mathrm{TCF} 3$ embryos, this difference was not measurably significant; however, there was a striking difference in the quality of the myelin lamellae between groups. There were significantly fewer PLLn axons surrounded by compacted membrane lamellae in $\Delta$ TCF3 embryos (Fig. $7 E$ ). Also, a significantly larger percentage of axons were ensheathed by lamellae that appeared to have stalled after enwrapment and had not progressed to the compaction stage (Fig. 7F). These observations suggest a failure in the normal progression of myelin formation in $\triangle \mathrm{TCF} 3$ embryos leading to hypomyelination. This is consistent with a crucial role for the $\mathrm{Wnt} / \beta$-catenin signaling in the early steps of myelin formation.

\section{Interaction between $\boldsymbol{\beta}$-catenin and TCF3 is required for the formation of central myelin}

We examined the expression of myelin genes in the CNS of zebrafish transgenic line $\Delta \mathrm{TCF} 3$. Embryos were heat shocked at $2 \mathrm{dpf}$, and myelin gene expression was assessed by in situ hybridization at $5 \mathrm{dpf}$. $m b p$ mRNA was also strongly reduced or even absent in oligodendrocytes of the CNS, pointing to the involvement of the Wnt pathway in CNS myelination (Fig. $8 a-c)$. We also examined $m p z$ and $p l p$ mRNA, which are specifically expressed in the zebrafish CNS. Their expression was severely reduced or even absent $(n=23$ of 32 ) in $\triangle \mathrm{TCF} 3$ embryos compared with controls (Fig. 8d-i). The in situ hybridization data were also validated by qRT-PCR at $4 \mathrm{dpf}$ (supplemental Fig. $3 c$, available at www.jneurosci.org as supplemental material).

It has been previously shown that Wnt signaling delays oligodendrocyte differentiation (Kim et al., 2008; Fancy et al., 2009). We thus examined whether heat shocking $\triangle \mathrm{TCF} 3$ embryos resulted in defective myelin gene expression because of altered oligodendrocyte development. We made use of the stable transgenic line olig2::EGFP, which selectively expresses GFP in oligodendrocytes and their precursors ( $\mathrm{Li}$, unpublished observations). No 
differences in oligodendrocyte development and distribution were observed between $\triangle \mathrm{TCF} 3$ and control embryos (Fig. $9 a, b)$. More important, the cell bodies and their extensions appeared normal (Fig. $9 c, d)$, and the number of cells counted on confocal sections in the same area of the hindbrain did not vary between controls (average, $30 ; n=5$ ) and $\Delta$ TCF3 embryos (average, $30.5 ; n=5 ; p>0.1$ ). Labeling embryos with acetylated tubulin revealed that axonal growth was also not affected in $\Delta$ TCF3 embryos (Fig. $9 e-j$ ). Together, these data indicate that defects in CNS myelination observed in $\triangle \mathrm{TCF} 3$ embryos are related to decreased myelin gene expression, rather than to altered axonal or oligodendroglial development.

As described above, Wnt signaling is required for $m b p$ expression before $3 \mathrm{dpf}$. To extend this analysis to other myelin genes in the brain, we examined $m p z$ and $p l p$ expression at $5 \mathrm{dpf}$ in $\triangle \mathrm{TCF} 3$ embryos heat shocked either at 2 or $3 \mathrm{dpf}$. We confirmed by qRT-PCR that the expression of both myelin protein mRNA are markedly reduced when embryos are heat shocked at 2 dpf. However, in contrast to $m b p, m p z$ and plp expression continues to be reduced by heat shocking $\triangle \mathrm{TCF} 3$ embryos as late as 3 dpf (Fig. $8 j-m$ ). These results show that $\beta$-catenin/TCF3 interaction is required for $m p z$ and $p l p$ expression during a more extended period in oligodendrocytes when compared with mbp expression.

We also tested the requirement of the $\mathrm{Wnt} / \beta$-catenin pathway for CNS myelination by injecting LRP $6 \Delta \mathrm{C}$, the dominantnegative form of LRP6. When compared with control embryos (Fig. 8n), $m p z$ and $p l p$ expression was reduced in $60 \%$ of the LRP6 $\Delta$ C-injected embryos (Fig. 80 ), showing normal oligodendrocyte development and axonal growth (data not shown). Together, our data demonstrate that the $\mathrm{Wnt} / \beta$-catenin pathway plays an essential role in myelin gene expression and in the onset of both oligodendrocyte and Schwann cell myelination in vivo.

\section{Discussion}

Although recent studies have examined the role of $\beta$-catenin signaling in oligodendrocyte development, we investigated the role of the Wnt/ $\beta$-catenin pathway in myelin gene expression and myelination. This was motivated by our previous finding of a Schwann cellspecific cross talk between $\beta$-catenin and steroid signaling (Fonte et al., 2005). Our results show that Wnt/ $\beta$-catenin signaling is a forward driver of myelin gene expression and myelin compaction.

\section{Components of the canonical Wnt signaling pathway drive myelin gene expression in Schwann cells and oligodendrocytes}

We first showed that major components of the $\mathrm{Wnt} / \beta$-catenin pathway colocalize with MBP immunoreactivity in the developing mouse sciatic nerve during the developmental period of my-
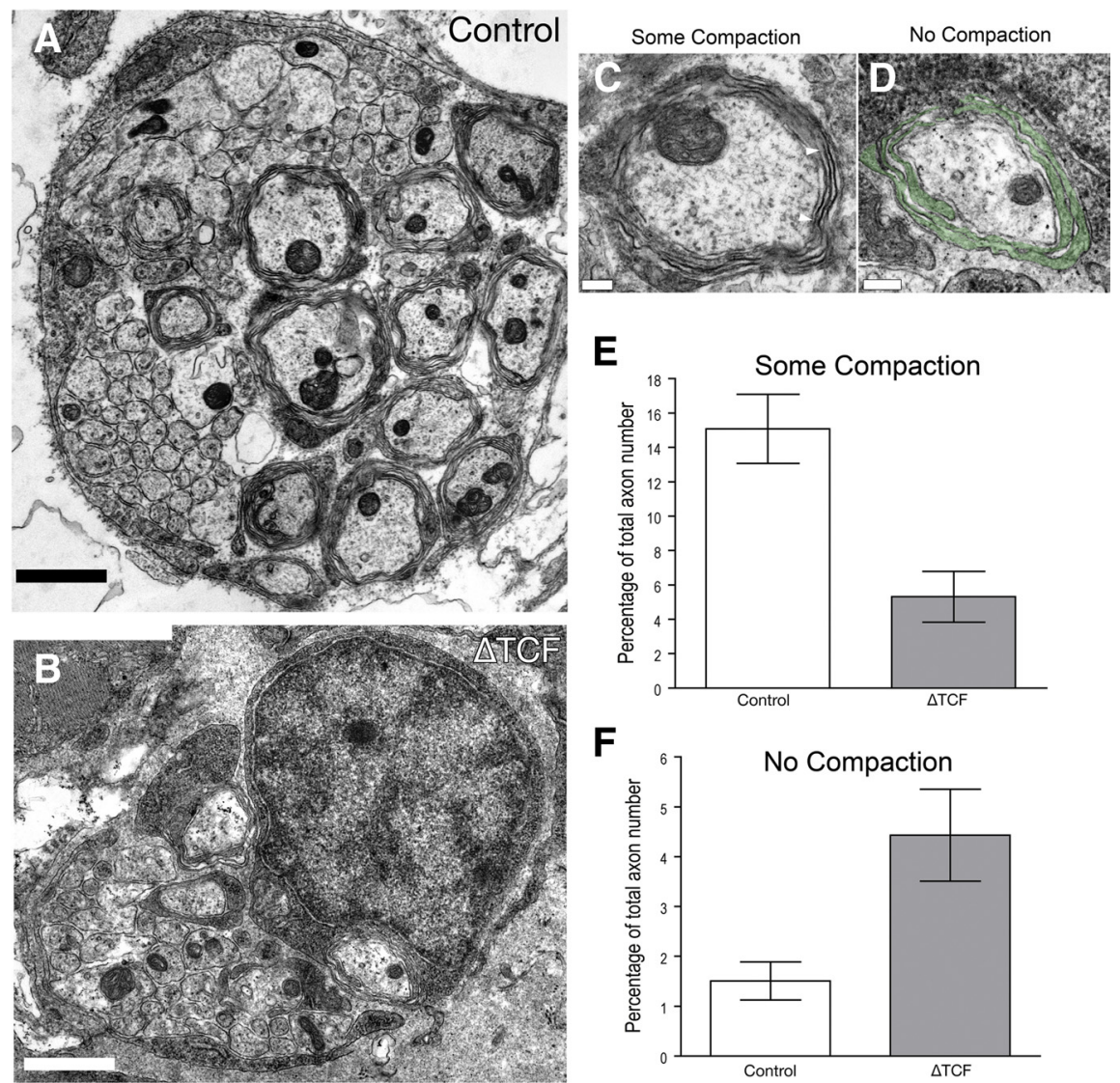

Figure 7. Schwann cells surround but do not myelinate axons in $\triangle T C F 3$ zebrafish embryos. $A, A$ cross section through the PLLn of a bryo PLLn at $4 \mathrm{dpf}$ an $6 \mathrm{hpf}$ and heat shocked at $48 \mathrm{hpf}$. C, High-power image of a control axon wrapped by several myelin lamellae that green). In contrast to the axon shown in these lamellae remain cytoplasmic and have not compacted to form the dark-stained compact lamellae. This is an example of an axon that was counted as having "no compaction" for quantification. Scale bars: $\boldsymbol{A}, \boldsymbol{B}, 1 \mu \mathrm{m} ; \boldsymbol{C}, \boldsymbol{D}, 200 \mathrm{~nm}$. $\boldsymbol{E}$, Quantification of the axons showing some compaction of myelin lamellae at $4 \mathrm{dpf}$ and $6 \mathrm{hpf}$. The bars illustrate the percentage of axons ensheathed by processes with some compact lamellae in control embryos and $\Delta$ TCF3 embryos heat shocked at 48 hpf. A significant 作 bars illustrate the percentage of axons ensheathed by lamellae without compaction lamellae in control embryos and $\Delta$ TCF3 embryos heat shocked at $48 \mathrm{hpf}$. A significant difference was found between control embryos (11 nerves from six embryos) and $\Delta$ TCF3 embryos (12 nerves from six embryos) (means \pm SEM; $p<0.01$ ). Images were scored blindly.

elination. Moreover, mRNA levels of Wnt ligands and major components (LRP6, DSH, $\beta$-catenin, TCF/LEF) correlate with those of peripheral myelin genes. Two observations point to a key role for Wnt signaling in Schwann cell myelination: (1) Schwann cells express Wnt ligand; and (2) the canonical Wnt signaling pathway is functional in Schwann cells, even in the absence of added Wnt ligand.

However, although endogenous Wnt is sufficient for myelin gene expression in Schwann cells, the addition of some Wnt ligands further increased MPZ and PMP22 mRNA and protein levels. This has allowed us to demonstrate the recruitment of $\beta$-catenin by TCF transcription factors at the level of the MPZ and PMP22 promoters by ChIP analysis. Interestingly, $\beta$-catenin expression was also upregulated by exposing the Schwann cell line to Wnt, pointing to a positive regulatory loop in Schwann cell $\mathrm{Wnt} / \beta$-catenin signaling (Fig. $4 c$ ).

Although peripheral and central myelin sheaths share many similarities, there are structural differences, and they differ in lipid composition and protein content. Moreover, signaling mol- 

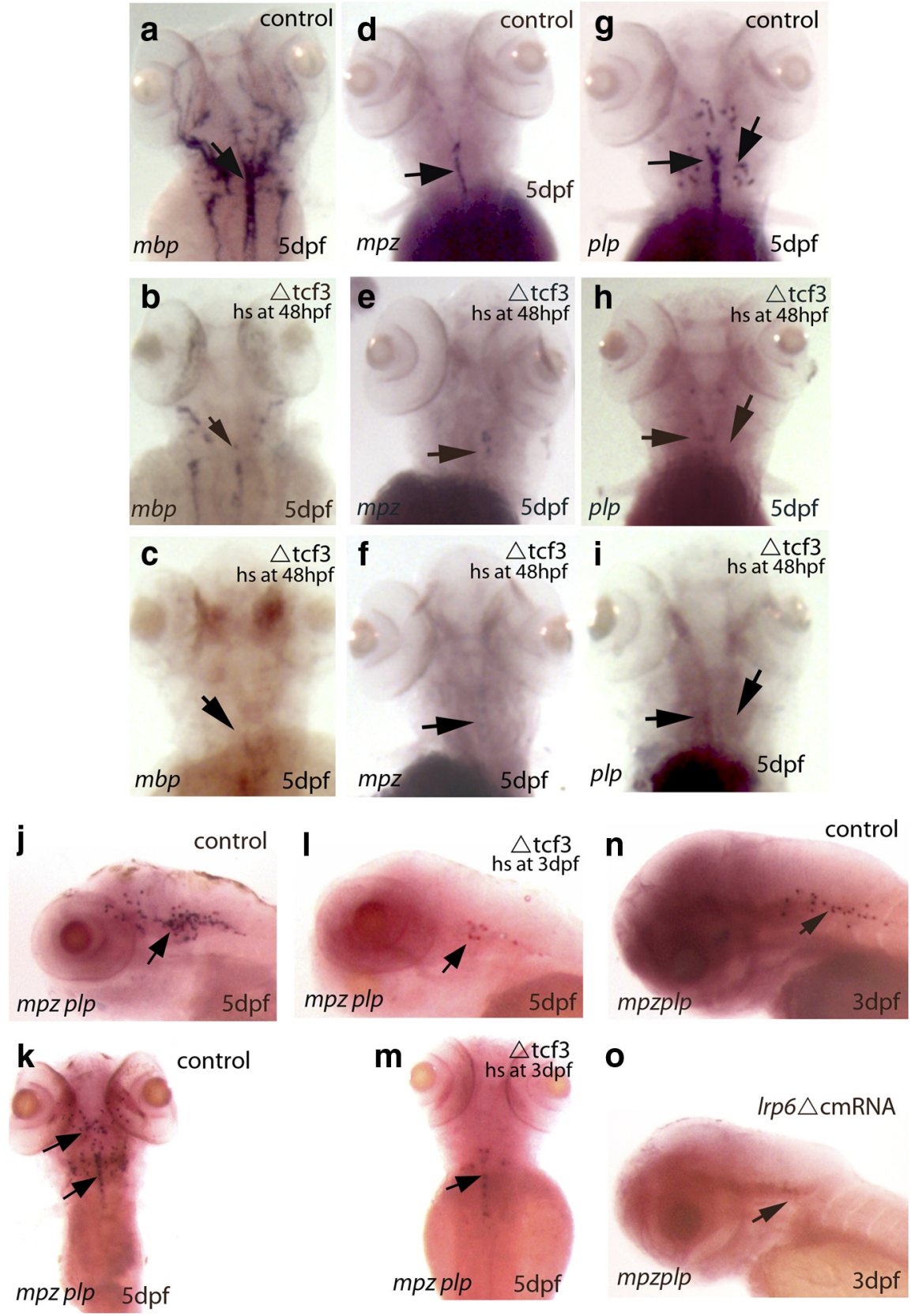

Figure 8. Analysis of oligodendrocyte myelination in $\triangle T C F 3$ zebrafish embryos and after LRP6 knockdown in the brain. $\boldsymbol{a}, \boldsymbol{d}, \boldsymbol{g}$, Dorsal views of $m b p$ (left), $m p z$ (middle), and $p / p$ (right) RNA expression (arrows) in the hindbrain of control embryos at $5 \mathrm{dpf}$ ( $n=$ 66 of 70$) . \boldsymbol{b}, \boldsymbol{e}, \boldsymbol{h}, \mathrm{mbp}, \mathrm{mpz}$, and plp RNA expression in the hindbrain of $\Delta \mathrm{TCF} 3$ embryos at $5 \mathrm{dpf}$, heat shocked at $48 \mathrm{hpf}$. A significant decrease in the expression of $m b p, m p z$, and $p / p$ is observed between controls and $\Delta T C F 3$ embryos. $\boldsymbol{c}, \boldsymbol{f}, \boldsymbol{i}, m b p, m p z$, and plp RNA expression in the hindbrain of $\Delta \mathrm{TCF} 3$ embryos at $5 \mathrm{dpf}$, heat shocked at $48 \mathrm{hpf}$, showing a more severe phenotype (almost no $m b p, m p z$, and $p / p$ expression). $\boldsymbol{j}, \boldsymbol{k}$, Lateral $(\boldsymbol{j})$ and dorsal ( $\boldsymbol{k}$ ) views of both $m p z$ and $p / p$ RNA expression in the hindbrain of control embryos at $5 \mathrm{dpf}$, indicated by arrows. $\boldsymbol{I}, \boldsymbol{m}$, Lateral $(\boldsymbol{I})$ and dorsal $(\boldsymbol{m})$ views of both $m p z$ and $p / p$ RNA expression in the hindbrain of $\Delta$ TCF3 embryos at $5 \mathrm{dpf}$, heat shocked at $3 \mathrm{dpf}$. A significant decrease in both mpz and $p / p$ expression is observed $(n=29$ of 35$)$. $\boldsymbol{n}$, Lateral view of both $m p z$ and $p / p$ RNA expression in control embryos at $3 \mathrm{dpf}(\boldsymbol{n}=30) . \boldsymbol{0}$, Lateral view of both $m p z$ and $p / p$ RNA expression in LRP6 $\Delta$ C-injected embryos at $3 \mathrm{dpf}(n=20)$. A marked decrease in both $m p z$ and $p / p$ expression is observed between controls and injected embryos. hs, Heat shocked.

ecules can have fundamentally different roles in peripheral and central myelination (Chan et al., 2004). Our results show that the $\mathrm{Wnt} / \beta$-catenin pathway is also an essential driver of myelin gene expression in oligodendrocytes and thus identify Wnt as a key regulator of myelin genes in both the PNS and CNS.

The knockdown of $\beta$-catenin expression by specific siRNA resulted in a noticeable reduction of MPZ and PMP22 promoter activities in the Schwann cell line and of PLP promoter activity in the oligodendrocyte cell line. However, linking $\beta$-catenin inhibition to canonical Wnt signaling requires a demonstration that Wnt activity upstream the TCF is involved in myelin gene expression. These evidences were obtained by inhibiting LRP6 and DSH with dominant-negative mutants and by knocking down TCF with specific siRNA. All these loss-of-function strategies resulted in the inhibition of myelin gene promoter activity.

\section{Canonical Wnt signaling is necessary to drive myelination in vivo}

A key role for the $\mathrm{Wnt} / \beta$-catenin pathway in PNS and CNS myelination was demonstrated by loss-of-function strategies in zebrafish embryos, which has become a powerful model to assess myelination in living embryos (Lyons et al., 2005; Kirby et al., 2006; Buckley et al., 2008). That is, most of the critical molecular machinery of myelination is conserved between zebrafish and mammals (Monk and Talbot, 2009). Most important, the zebrafish model allows us to precisely study signaling mechanisms at the onset of myelination.

The binding of $\beta$-catenin to TCF3 was disrupted in the inducible transgenic zebrafish line $\triangle \mathrm{TCF} 3$ by heat shock, and Wnt signaling upstream of $\beta$-catenin was inhibited by injecting embryos with a dominantnegative construct of LRP6 (LRP6 $\Delta$ C). In Schwann cells, the impact of Wnt impairment at $2 \mathrm{dpf}$ on myelination was based on (1) the inhibition of myelin gene expression and (2) an arrest of myelin formation at a very early stage of axonal wrapping. Moreover, the extent and severity of the generated phenotypes were dependent on the degree of Wnt pathway inactivation, and this was true for the transcriptional function of $\beta$-catenin (TCF) and for Wnt receptor (LRP6) activity. However, the rate of Schwann cell proliferation was not affected in LRP6 $\Delta$ C-injected embryos, contrary to embryos with reduced $\beta$-catenin (Gess et al., 2008), a difference that might be related to $\beta$-catenin being at the crossroad of several pathways including $\mathrm{Wnt} / \beta$-catenin and serine/threonine kinase Akt.

Together, these results suggest that Wnt $/ \beta$-catenin signaling can modulate myelin gene expression in Schwann cells independently of cell proliferation. Similarly to Schwann cells, oligodendrocyte myelination was severely affected by preventing the interaction between $\beta$-catenin and TCF3 or by inhibiting LRP6. Thus, the $\mathrm{Wnt} / \beta$-catenin pathway is also required for myelin formation by oligodendrocytes. Most important, disrupting Wnt signaling inhibited myelination in the different compartments of the nervous system without affecting axons and the 

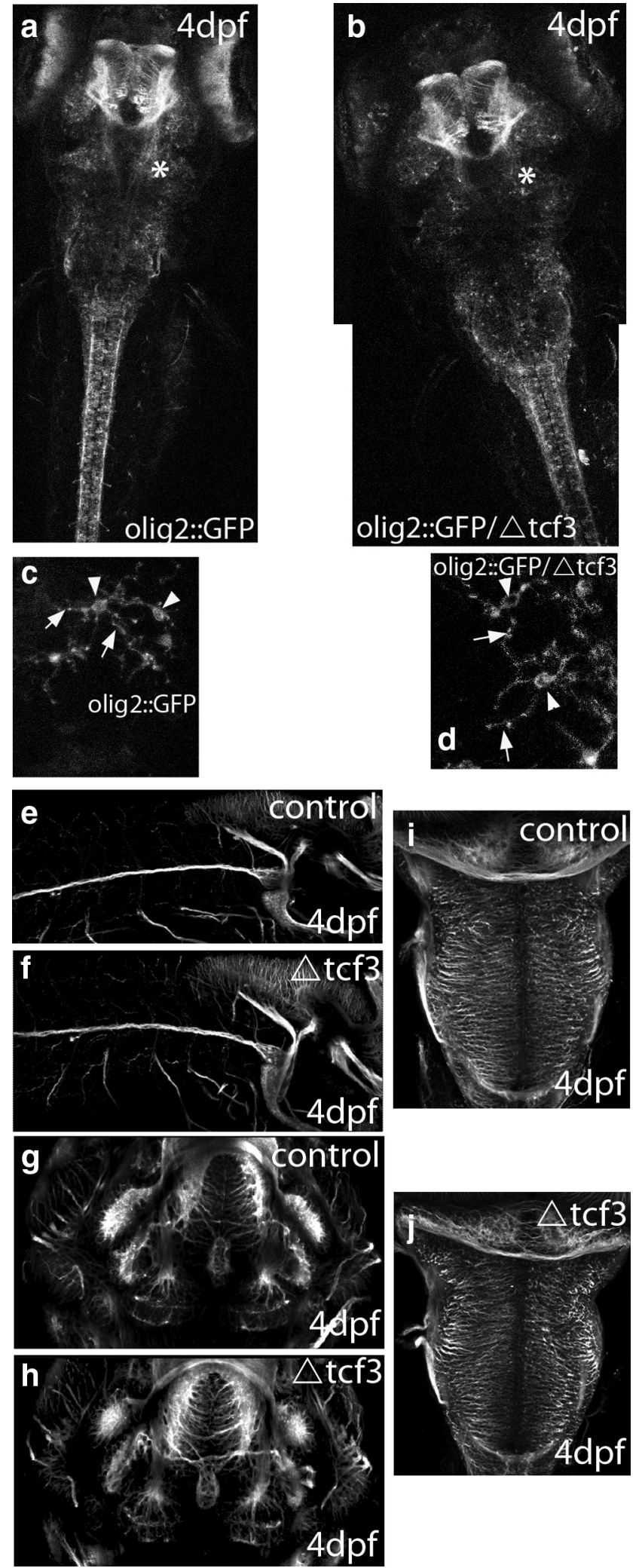

Figure 9. Phenotypic analyses of $\triangle T$ TCF3 embryos in the brain. $\boldsymbol{a}, \boldsymbol{b}$, Confocal images of olig2::GFP embryos at $4 \mathrm{dpf}$ in control embryos $(\boldsymbol{a} ; n=10$ of 10$)$ and $\Delta \mathrm{TCF} 3$ embryos $(\boldsymbol{b} ; n=$ 9 of 10) heat shocked at $48 \mathrm{hpf}$. The overall pattern of olig2 expression is similar between controls and $\Delta \mathrm{TCF} 3$ embryos. $\boldsymbol{c}, \boldsymbol{d}$, Magnified view of oligo2-expressing cells from the hindbrain area (indicated by an asterisk in $\boldsymbol{a}$ and $\boldsymbol{b}$ ) of control embryos (c) and $\Delta \mathrm{TCF} 3$ embryos (d) heat shocked at $48 \mathrm{hpf}$. Arrowheads indicate the bodies of these cells, and arrows point to their extensions. No significant difference in olig2::GFP cell development, survival, and morphology is observed between controls and $\Delta \mathrm{TCF} 3$ embryos. $\boldsymbol{e}, \boldsymbol{g}, \boldsymbol{i}$, Confocal images of lateral (e), ventral generation of Schwann cells or oligodendrocytes. Because of a lack of specific OPC markers in zebrafish, and since olig2 is expressed in both oligodendrocytes and their precursors, it is not conceivable to call the olig2:GFP/DTCF3 cells as classical OPCs or oligodendrocytes. Although they have the same morphology as oligodendrocytes in control embryos, they do not express myelin genes, and they are more likely to be oligodendrocyte-like cells arrested at a promyelinating stage.

How does Wnt signaling regulate myelin gene expression in Schwann cells and oligodendrocytes? Our in vivo $\triangle \mathrm{TCF} 3$ and LRP $6 \Delta \mathrm{C}$ analyses are not specifically restricted to these two lineages, therefore we cannot rule out that the phenotype we observe is related to a cross talk between neurons and myelinating cells. However, taking our in vivo and in vitro results together, we suggest that the $\mathrm{Wnt} / \beta$-catenin pathway regulates myelination, at least in part, by driving myelin gene expression in Schwann cells and oligodendrocytes.

Another finding was that the $\beta$-catenin/TCF3 interaction is primarily required for $m b p$ expression in oligodendrocytes and Schwann cells at the time when they start myelinating axons, precisely before $3 \mathrm{dpf}$ (Brosamle and Halpern, 2002). Consistent with a crucial role for $\mathrm{Wnt} / \beta$-catenin signaling in the very early steps of Schwann cell myelination was the failure to form compacted myelin sheaths in embryos with early disruption of TCF function. However, our results suggest that $\beta$-catenin/TCF3 interaction may be required for $m p z$ and $p l p$ expression during a more extended period in oligodendrocytes. This may not be particularly related to differences between PNS and CNS myelination as $m b p$ is expressed in the PNS and CNS in zebrafish and is downregulated in both tissues after $\triangle \mathrm{TCF} 3$ heat shock, but more probably to differences in the regulation of myelin genes: $m b p$ versus $m p z$ and $p l p$.

\section{Roles of canonical Wnt signaling in oligodendrocyte maturation and myelination}

Three recent studies have addressed the potential role of Wnt signaling in oligodendrocyte development. Constitutive activation of $\beta$-catenin or inhibition of Adenomatous Polyposis Coli expression, resulting in the stabilization of $\beta$-catenin, delayed oligodendrocyte differentiation (Fancy et al., 2009; Feigenson et al., 2009). Likewise, the constitutive stabilization and nuclear translocation of $\beta$-catenin in cells of the oligodendrocyte lineage had a negative influence on oligodendrocyte maturation. However, the targeted disruption of TCF7L2 in mice led to severe defects in oligodendrocyte differentiation but not specification (Ye et al., 2009). Based on these findings, the consensus has emerged that canonical Wnt signaling may exert a repressive effect on oligodendrocyte differentiation and on myelination. When interpreting the results of the previous studies, the following points should be taken into consideration: (1) experiments based on the disruption of TCF function are consistent with a key role of $\beta$-catenin signaling in oligodendrocyte differentiation similar to our findings; (2) constitutive activation of $\beta$-catenin signaling may result in the dysregulation of gene expression; and (3) the Wnt signaling components so far examined in oligodendrocyte development ( $\beta$-catenin, APC, and TCF) are all shared

$\leftarrow$

$(\boldsymbol{g})$, and dorsal (i) views of olig2::GFP at $4 \mathrm{dpf} . \boldsymbol{f}, \boldsymbol{h}, \boldsymbol{j}$, Confocal images of lateral $(\boldsymbol{f})$, ventral $(\boldsymbol{h})$, and dorsal (j) views of olig2::GFP/ $\Delta$ TCF3 embryos at $4 \mathrm{dpf}$, heat shocked at $48 \mathrm{hpf}$. No significant difference in axonal growth and patterning was observed between controls and $\triangle \mathrm{TCF} 3$ embryos. 
between the canonical Wnt and other major signaling pathways, in particular the PI3/AKT pathway (Nelson and Nusse, 2004; Ding et al., 2007; Blankesteijn et al., 2008; Welters and Kulkarni, 2008).

In immature OPCs isolated from neonatal rat brain, Wnt does not activate myelin gene expression. However, at a more differentiated stage, Wnt signaling becomes stimulating. This is consistent with our observation that Wnt increases PLP expression in mature oligodendrocytes in primary cultures and in $158 \mathrm{~N}$ cells, which express characteristics of mature oligodendrocytes.

This discrepancy could be explained by different functions of canonical Wnt signaling during oligodendrocyte specification, differentiation, and the process of myelination. It is definitely well established that signaling systems can exert different actions at distinct developmental stages (Woodhoo et al., 2009). For example, Kalani et al. (2008) have demonstrated that Wnt signaling is required to generate oligodendrocytes from neural stem cells, whereas others (Fancy et al., 2009; Ye et al., 2009) show a delay in oligodendrocyte differentiation in cultures derived from OPCs or when activating $\beta$-catenin from early stages. Finally, here we demonstrate that the inhibition of canonical Wnt signaling in oligodendrocytes impairs the onset of myelin formation via the failure of myelin genes to be activated. Therefore, the Wnt pathway may regulate the myelination process differentially at each step of this complex process. Our findings thus contribute to a clearer understanding of the fine-tuning of the myelination process and identify components of the $\mathrm{Wnt} / \beta$-catenin pathway as promising drug candidates for promoting myelination.

\section{References}

Baron-Van Evercooren A, Duhamel-Clerin E, Boutry JM, Hauw JJ, Gumpel M (1993) Pathways of migration of transplanted Schwann cells in the demyelinated mouse spinal cord. J Neurosci Res 35:428-438.

Bienz M (1998) TCF: transcriptional activator or repressor? Curr Opin Cell Biol 10:366-372.

Blankesteijn WM, van de Schans VA, ter Horst P, Smits JF (2008) The Wnt/ frizzled/GSK-3 beta pathway: a novel therapeutic target for cardiac hypertrophy. Trends Pharmacol Sci 29:175-180.

Boutry JM, Hauw JJ, Gansmuller A, Di-Bert N, Pouchelet M, Baron-Van Evercooren A (1992) Establishment and characterization of a mouse Schwann cell line which produces myelin in vivo. J Neurosci Res 32:15-26.

Brosamle C, Halpern ME (2002) Characterization of myelination in the developing zebrafish. Glia 39:47-57.

Buckley CE, Goldsmith P, Franklin RJ (2008) Zebrafish myelination: a transparent model for remyelination? Dis Model Mech 1:221-228.

Cavallo RA, Cox RT, Moline MM, Roose J, Polevoy GA, Clevers H, Peifer M, Bejsovec A (1998) Drosophila Tcf and Groucho interact to repress Wingless signalling activity. Nature 395:604-608.

Chan JR, Watkins TA, Cosgaya JM, Zhang C, Chen L, Reichardt LF, Shooter EM, Barres BA (2004) NGF controls axonal receptivity to myelination by Schwann cells or oligodendrocytes. Neuron 43:183-191.

Chen G, Fernandez J, Mische S, Courey AJ (1999) A functional interaction between the histone deacetylase $\mathrm{Rpd} 3$ and the corepressor groucho in Drosophila development. Genes Dev 13:2218-2230.

Ding Q, He X, Xia W, Hsu JM, Chen CT, Li LY, Lee DF, Yang JY, Xie X, Liu JC, Hung MC (2007) Myeloid cell leukemia-1 inversely correlates with glycogen synthase kinase-3beta activity and associates with poor prognosis in human breast cancer. Cancer Res 67:4564-4571.

Fancy SP, Baranzini SE, Zhao C, Yuk DI, Irvine KA, Kaing S, Sanai N, Franklin RJ, Rowitch DH (2009) Dysregulation of the Wnt pathway inhibits timely myelination and remyelination in the mammalian CNS. Genes Dev 23:1571-1585.

Feigenson K, Reid M, See J, Crenshaw EB 3rd, Grinspan JB (2009) Wnt signaling is sufficient to perturb oligodendrocyte maturation. Mol Cell Neurosci 42:255-265.
Feutz AC, Pham-Dinh D, Allinquant B, Miehe M, Ghandour MS (2001) An immortalized jimpy oligodendrocyte cell line: defects in cell cycle and cAMP pathway. Glia 34:241-252.

ffrench-Constant C, Colognato H, Franklin RJ (2004) Neuroscience. The mysteries of myelin unwrapped. Science 304:688-689.

Fonte C, Grenier J, Trousson A, Chauchereau A, Lahuna O, Baulieu EE, Schumacher M, Massaad C (2005) Involvement of $\beta$-catenin and unusual behavior of CBP and p300 in glucocorticosteroid signaling in Schwann cells. Proc Natl Acad Sci U S A 102:14260-14265.

Gao X, Arlotta P, Macklis JD, Chen J (2007) Conditional knock-out of $\beta$-catenin in postnatal-born dentate gyrus granule neurons results in dendritic malformation. J Neurosci 27:14317-14325.

Gess B, Halfter H, Kleffner I, Monje P, Athauda G, Wood PM, Young P, Wanner IB (2008) Inhibition of N-cadherin and beta-catenin function reduces axon-induced Schwann cell proliferation. J Neurosci Res 86:797-812.

Gilmour DT, Maischein HM, Nusslein-Volhard C (2002) Migration and function of a glial subtype in the vertebrate peripheral nervous system. Neuron 34:577-588.

Jessen KR, Mirsky R (2005) The origin and development of glial cells in peripheral nerves. Nat Rev Neurosci 6:671-682.

Kalani MY, Cheshier SH, Cord BJ, Bababeygy SR, Vogel H, Weissman IL, Palmer TD, Nusse R (2008) Wnt-mediated self-renewal of neural stem/ progenitor cells. Proc Natl Acad Sci U S A 105:16970-16975.

Kazakova N, Li H, Mora A, Jessen KR, Mirsky R, Richardson WD, Smith HK (2006) A screen for mutations in zebrafish that affect myelin gene expression in Schwann cells and oligodendrocytes. Dev Biol 297:1-13.

Kim S, Kim SH, Kim H, Chung AY, Cha YI, Kim CH, Huh TL, Park HC (2008) Frizzled 8a function is required for oligodendrocyte development in the zebrafish spinal cord. Dev Dyn 237:3324-3331.

Kirby BB, Takada N, Latimer AJ, Shin J, Carney TJ, Kelsh RN, Appel B (2006) In vivo time-lapse imaging shows dynamic oligodendrocyte progenitor behavior during zebrafish development. Nat Neurosci 9:1506-1511

Lai SL, Chien AJ, Moon RT (2009) Wnt/Fz signaling and the cytoskeleton: potential roles in tumorigenesis. Cell Res 19:532-545.

Lee HY, Kleber M, Hari L, Brault V, Suter U, Taketo MM, Kemler R, Sommer L (2004) Instructive role of Wnt/beta-catenin in sensory fate specification in neural crest stem cells. Science 303:1020-1023.

Lewis JL, Bonner J, Modrell M, Ragland JW, Moon RT, Dorsky RI, Raible DW (2004) Reiterated Wnt signaling during zebrafish neural crest development. Development 131:1299-1308.

Lyons DA, Pogoda HM, Voas MG, Woods IG, Diamond B, Nix R, Arana N, Jacobs J, Talbot WS (2005) erbb3 and erbb2 are essential for Schwann cell migration and myelination in zebrafish. Curr Biol 15:513-524.

Mallon BS, Shick HE, Kidd GJ, Macklin WB (2002) Proteolipid promoter activity distinguishes two populations of NG2-positive cells throughout neonatal cortical development. J Neurosci 22:876-885.

Massaad C, Garlatti M, Wilson EM, Cadepond F, Barouki R (2000) A natural sequence consisting of overlapping glucocorticoid-responsive elements mediates glucocorticoid, but not androgen, regulation of gene expression. Biochem J 350:123-129.

Megason SG, McMahon AP (2002) A mitogen gradient of dorsal midline Wnts organizes growth in the CNS. Development 129:2087-2098.

Monk KR, Talbot WS (2009) Genetic dissection of myelinated axons in zebrafish. Curr Opin Neurobiol 19:486-490.

Nelson WJ, Nusse R (2004) Convergence of Wnt, beta-catenin, and cadherin pathways. Science 303:1483-1487.

Nusse R (1999) WNT targets. Repression and activation. Trends Genet 15:1-3.

Park HC, Kim CH, Bae YK, Yeo SY, Kim SH, Hong SK, Shin J, Yoo KW, Hibi M, Hirano T, Miki N, Chitnis AB, Huh TL (2000) Analysis of upstream elements in the $\mathrm{HuC}$ promoter leads to the establishment of transgenic zebrafish with fluorescent neurons. Dev Biol 227:279-293.

Salinas PC, Zou Y (2008) Wnt signaling in neural circuit assembly. Annu Rev Neurosci 31:339-358.

Tada M, Smith JC (2000) Xwnt11 is a target of Xenopus Brachyury: regulation of gastrulation movements via Dishevelled, but not through the canonical Wnt pathway. Development 127:2227-2238. 
Tamai K, Semenov M, Kato Y, Spokony R, Liu C, Katsuyama Y, Hess F, Saint-Jeannet JP, He X (2000) LDL-receptor-related proteins in Wnt signal transduction. Nature 407:530-535.

Toledo EM, Colombres M, Inestrosa NC (2008) Wnt signaling in neuroprotection and stem cell differentiation. Prog Neurobiol 86:281296.

Trousson A, Bernard S, Petit PX, Liere P, Pianos A, El Hadri K, Lobaccaro JM, Ghandour MS, Raymondjean M, Schumacher M, Massaad C (2009) 25Hydroxycholesterol provokes oligodendrocyte cell line apoptosis and stimulates the secreted phospholipase A2 type IIA via LXR beta and PXR. J Neurochem 109:945-958.

van Beest M, Dooijes D, van De Wetering M, Kjaerulff S, Bonvin A, Nielsen O, Clevers H (2000) Sequence-specific high mobility group box factors recognize 10-12-base pair minor groove motifs. J Biol Chem 275:27266-27273.

Welters HJ, Kulkarni RN (2008) Wnt signaling: relevance to beta-cell biology and diabetes. Trends Endocrinol Metab 19:349-355.

Woodhoo A, Alonso MB, Droggiti A, Turmaine M, D'Antonio M, Parkinson DB, Wilton DK, Al-Shawi R, Simons P, Shen J, Guillemot F, Radtke F, Meijer D, Feltri ML, Wrabetz L, Mirsky R, Jessen KR (2009) Notch controls embryonic Schwann cell differentiation, postnatal myelination and adult plasticity. Nat Neurosci 12:839-847.

Ye F, Chen Y, Hoang T, Montgomery RL, Zhao XH, Bu H, Hu T, Taketo MM, van Es JH, Clevers H, Hsieh J, Bassel-Duby R, Olson EN, Lu QR (2009) HDAC1 and HDAC2 regulate oligodendrocyte differentiation by disrupting the beta-catenin-TCF interaction. Nat Neurosci 12:829-838. 